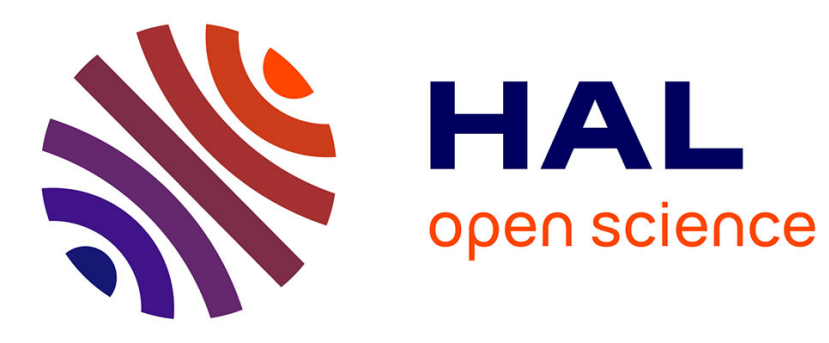

\title{
Hydroxamates: Relationships between Structure and Plasma Stability
}

Marion Flipo, Julie Charton, Akila Hocine, Sandrine Dassonneville, Benoit Deprez, Rébecca F. Déprez-Poulain

\section{- To cite this version:}

Marion Flipo, Julie Charton, Akila Hocine, Sandrine Dassonneville, Benoit Deprez, et al.. Hydroxamates: Relationships between Structure and Plasma Stability. Journal of Medicinal Chemistry, 2009, 52 (21), pp.6790-6802. 10.1021/jm900648x . hal-03051799

HAL Id: hal-03051799

https://hal.science/hal-03051799

Submitted on 10 Dec 2020

HAL is a multi-disciplinary open access archive for the deposit and dissemination of scientific research documents, whether they are published or not. The documents may come from teaching and research institutions in France or abroad, or from public or private research centers.
L'archive ouverte pluridisciplinaire $\mathbf{H A L}$, est destinée au dépôt et à la diffusion de documents scientifiques de niveau recherche, publiés ou non, émanant des établissements d'enseignement et de recherche français ou étrangers, des laboratoires publics ou privés. 


\section{Hydroxamates: Relationships between}

\section{structure and plasma-stability.}

Marion Flipo ; Julie Charton; Akila Hocine ; Sandrine Dassonneville ; Benoit Deprez*;

Rebecca Deprez-Poulain*

${ }^{a}$ INSERM U761 Biostructures and Drug Discovery, Lille F-59006, France

${ }^{b}$ Faculté de Pharmacie, Univ Lille Nord de France, Lille F-59006, France

${ }^{c}$ Institut Pasteur de Lille, IFR 142, Lille F-59021, France

${ }^{d}$ PRIM, Lille F-59006, France.

\footnotetext{
${ }^{*}$ Corresponding authors : R. Deprez-Poulain or B. Deprez Biostructures and Drug Discovery, INSERM U761, Faculté de Pharmacie, Univ Lille Nord de France, 3 rue du Pr Laguesse Lille F-59006, France, Fax: (+33) 320964709

E-mail: rebecca.deprez@univ-lille.fr; benoit.deprez@univ-lille.fr

Homepages:

www.deprezlab.fr

a Abbreviations. AcOEt : ethyl acetate; $\mathrm{AcOH}$ : acetic acid; $\mathrm{CDI}: \mathrm{N}, \mathrm{N}$ 'carbonyldiimidazole; $\mathrm{CH}_{3} \mathrm{CN}$ : acetonitrile; DCM : dichloromethane; DIEA : diisopropylethylamine; DMF : dimethylformamide; DMSO : dimethylsulfoxide; EDCI : N-ethyl-3-(3-dimethyaminopropyl)-carbodiimide; $\mathrm{Et}_{2} \mathrm{O}$ : diethyl ether; $\mathrm{EtOH}$ : ethanol; EWG : Electron-withdrawing group; HOBT : $N$-hydroxybenzotriazole; $\mathrm{MeOH}:$ methanol; PyBrop : bromo-tris-pyrrolidinophosphonium hexafluorophosphate; TEA : triethylamine; TFA : trifluoroacetic acid ; THF : tetrahydrofuran ; Trt : trityl.
} 


\begin{abstract}
Hydroxamates are valuable tools for chemical biology as well as interesting leads for medicinal chemistry. Though many hydroxamates display nanomolar activities against metalloproteases, only three hydroxamates have reached the market, among which is the HDAC inhibitor vorinostat. Failures in development are generally attributed to lack of selectivity, toxicity or poor stability. To help medicinal chemists with respect to plasma stability, we have performed the first and preliminary study on structure-plasma stability for hydroxamates. We define some structural rules to predict or improve the plasma stability in the preclinical stage.
\end{abstract}

\title{
Keywords
}

Plasma stability; hydroxamates; half-life; hydroxamic acids; rat; in vitro 


\section{Introduction}

Hydroxamic acids are often potent bioactive molecules. ${ }^{1,2}$ Due to their chelating group, they target metalloproteases and can serve as both biological probes ${ }^{3}$ and leads. They can also be used as bioisosters of carboxylic acid, being weak acids. ${ }^{4}$ Recently reported biological activities of these compounds include: inhibition of peptide deformylase (PDF) or of botulinum neurotoxin A protease. ${ }^{5,6}$ Also, inhibition of the protease responsible for the shedding of the extracelullar domain of HER-2 by hydroxamates has been described. ${ }^{7}$ Furthermore, inhibition of aggrecanases by hydroxamates has been reported in the literature, following the initial work on matrix metalloproteases (MMP). ${ }^{8}$ The related Tumor Necrosis Factor Converting Enzyme (TACE, ADAM17) is also inhibited by hydroxamates. ${ }^{9}$ Other hydroxamates are active on Plasmodium falciparum, either by inhibiting metalloproteases or zinc hydrolases like Histone Deacetylases (HDAC). ${ }^{10,11}$ Finally, the field of human Histone Deacetylase hydroxamate inhibitors has been extensively studied, and led to the successful development of vorinostat (SAHA). ${ }^{12}$

Though hydroxamates are often very potent enzyme inhibitors, several challenges need to be addressed in the context of drug discovery. Firstly, a relatively low selectivity (due to a significant contribution of $\mathrm{Zn}$ binding to their affinity to the target) may lead to several adverse effects. For example, broad MMP inhibition in patients gives rise to "stiffening" of the joints referred to as musculo-skeletal syndrome (MSS). ${ }^{13}$ Although this lack of selectivity hampered clinical development of the first generation of inhibitors, the discovery of more selective hydroxamates has been possible thanks to chemical modulation. ${ }^{14}$ Secondly, pharmacokinetics and toxicological issues are not easily solved. These challenges have forced medicinal chemists to search for surrogates for this highly efficient zinc binding group 
(ZBG). ${ }^{15}$ For example, some teams have shifted back to carboxylic acids or tetrazoles. ${ }^{16,17}$ Other series include o-aminobenzamides or retro-hydroxamates. ${ }^{18,19}$ Nevertheless, after 25 years, the first hydroxamate was approved in 2006 for marketing: vorinostat (SAHA, Merck\&Co), a histone deacetylase (HDAC) inhibitor for the treatment of cancer. ${ }^{20}$ Hydroxamic acids may be hydrolyzed to the corresponding carboxylic acid under physiological conditions (Scheme 1). ${ }^{21}$ Although involvement of the liver aldehyde oxidase was proposed, the hydrolytic activity of the plasma is the most widely accepted explanation. ${ }^{22,23,24}$ Some hydroxamates are prone to hydrolysis in plasma. This is deleterious to their distribution and efficiency since the carboxylic acid is generally much less active. Hydrolysis may also contribute to toxicity, because of the mutagenicity of the by-product hydroxylamine. ${ }^{25}$ Other metabolites of the hydroxamic function include glucuronides and sulfonates. ${ }^{26,27}$ Recently, glycosylhydroxamates have been proposed as pro-drugs. ${ }^{28}$

Though many hydroxamates are disclosed in the literature, as well as their pharmacokinetics, no consistent information is yet available on structure-plasma stability relationships (SPSR). We and other groups have tried to improve the pharmacokinetics properties of hydroxamates by chemical modulation. ${ }^{10,29}$ Unstable molecules exhibit a rapid clearance and short half-life, resulting in poor in vivo exposure of the organism and thus poor bioactivity. Determining plasma stability is critical for prioritizing compounds before in vivo experiments. This is therefore an important driver for the medicinal chemist. We report here the first and preliminary in vitro structure-plasma stability relationships (SPSR) of hydroxamates in rat plasma that could be useful for drug design. We discuss the structural features that potentially affect in-vitro stability and relate our findings to those reported in the literature on hydroxamates. 


\section{Chemistry}

Compounds 1-3 (Figure 1) were synthesized as previously described..$^{10}$ Compound $\mathbf{1}$ and (Z)2 were respectively a hit and a lead, which were identified in our optimisation program aiming at the development of inhibitors of the plasmodial Zinc metalloprotease PfAM1. ${ }^{10}$ In the course of this program, several analogues were developed for SAR purposes and also for structure-plasma stability relationships (SPSR). Syntheses of compounds 4-11 are described in schemes 2-5. Compound 4 was obtained in 3 steps from 2-benzylmalonic acid monoethyl ester (Scheme 2). Coupling of $\mathrm{N}$-methylhydroxylamine required some optimization since the classical protocol used for unsubstituted hydroxylamine (e.g. activation by oxalyl chloride) was unsuccessful (Table 1). The best activator was PyBrop (Table 1). Compound 5 was designed as a prodrug of $\mathbf{1} \cdot{ }^{30}$ Its synthesis proceeds as described in Scheme 3, giving $\mathbf{5}$ with an overall yield of $50 \%$. Indeed the ethyl ester derivative is a major by-product. ${ }^{31}$ Compounds 6 and 8-10 were obtained from the corresponding substituted diethylmalonate, using Ntritylhydroxylamine (Scheme 4). Compound 6 required the synthesis of the 2-benzyl-2methylmalonic acid diethyl ester precursor. Hydroxamate 7 was obtained from the chlorocarbonylacetic acid ethyl ester (Scheme 4). Compound $\mathbf{1 1}$ differs from $\mathbf{1}$ by the inversion of amide function, and was obtained from phenylalanine using a solid support strategy that allowed both anchoring and protection of the hydroxamate moiety (Scheme 5).

A second series of compounds was investigated with the aim of varying the structure and length of the chain between the terminal hydroxamic moiety and an aryl group (compounds 12-22).

These compounds were obtained from the corresponding carboxylic acid and O-tritylhydroxylamine by activation using either oxalylchloride or EDCI/HOBt (Scheme 6). For compound 19, the acid precursor was synthesized by a Sonogashira reaction from the corresponding acetylenic derivative and 4-iodobenzoic ethyl ester (Scheme 6). Compound 22 
derived from N-Boc- $L$-phenylalanine (Scheme 6). Finally, SAHA and compounds 20-21 were synthesized as reported in the literature (Scheme 7). ${ }^{32-33}$

\section{Plasma stabilities}

Rat plasma stabilities were evaluated for hydroxamates 1-22 and expressed as their corresponding half-lives. The stability of $\mathbf{1}$ was also measured in the presence of phenylmethylsulfonyl fluoride (PMSF), an esterase inhibitor. Stability of compounds 1, (Z)-2, (E)-2, 14 and 15 was further evaluated in human plasma. In all cases, quantification was performed in duplicate using LC-MSMS (MRM or SIM detection modes), in the presence of an internal standard.

\section{Results and discussion.}

\section{$\underline{\text { Evidencing esterase implication }}$}

All compounds are stable when incubated in potassium phosphate buffer ( $\mathrm{pH} 7.4)$, suggesting that degradation occurring in rat plasma was most likely enzymatic. ${ }^{34}$ In order to demonstrate the esterasic activity of plasma, we preincubated rat plasma with $2 \mathrm{mM}$ PMSF (phenylmethylsulfonyl fluoride) a known broad spectrum serine-hydrolase inhibitor, in experiments aiming at the measurement of the half-life of $\mathbf{1}$ (Table 2). The increase in halflife in the presence of PMSF is similar to that of enalapril, an ester prodrug known to be hydrolyzed by plasma esterases, showing that hydrolysis is enzyme-dependent.

\section{$\underline{\text { Rat plasma stabilities }}$}

In-vitro half-lives of compounds in rat plasma are presented in Tables 3-6. The following paragraphs are based largely on pairwise comparisons of plasma stabilities. These results are consolidated and put into perspective in the Discussion summary part. 
Influence of substituent and spacer in arylalkanoic hydroxamate derivatives. In the series designed to explore the influence of the length and nature of the chain between the aryl ring and the hydroxamate function, large variations of half-lives are observed (11-22, Table 4). While benzohydroxamic and phenylacetohydroxamic acids $\mathbf{1 2}$ and $\mathbf{1 3}$ are very stable, the homologous compound $\mathbf{1 4}$ is much less stable. Summers et al. showed for hydroxamate derivatives of ibuprofen, that an important structural feature for resistance to metabolism is the spacer unit between the hydroxamate group and the phenyl ring. ${ }^{35}$. They concluded that introduction of a larger spacer enhances metabolism to the corresponding carboxylic acid. However, we believe that the dramatic drop in stability observed in our series between $\mathbf{1 3}$ and 14 cannot be explained solely by the increase of accessibility of the carbonyl center. In fact, SAHA which has the longest alkylidene spacer has an intermediate half-life of $9.7 \mathrm{~h}$ (Table 4). Rather, recognition of the phenyl group by esterases is likely to be a key component of hydrolysis.

Interestingly, replacing a methylene moiety by an oxygen atom does not alter the half-life (15 vs 18) or increases the half-life by $100 \%$ (14 vs $\mathbf{1 7}$ ). Decreasing flexibility (due to the introduction of a trans double bond) better protects from hydrolysis (16 vs 14). Interestingly, hydroxamate $\mathbf{1 9}$ is less stable than its analogue 12. An explanation could be that $\mathbf{1 9}$ has a greater lipophilicity $(\mathrm{A} \log \mathrm{P}=2.2 \text { and } 0.8 \text { for } 19 \text { and } 12 \text { respectively })^{36}$ and that this longer substituent enhances the hydrophobic contact with the esterases. ${ }^{37}$ Along with the possible hydrogen bond with $\mathrm{NH}$ in $\mathbf{2 2}$, this explanation could also be valid for the difference between 14 and 22, the latter bearing an additional hydrophobic tBoc-amino group (AlogP $=1.3$ and 1.8 for 14 and 22 respectively).

Phenylalanine derivatives $\mathbf{1 1}$ and $\mathbf{2 2}$ that bear a benzyl group in alpha to the hydroxamate are rapidly hydrolyzed. In contrast, compounds $\mathbf{2 0}$ and $\mathbf{2 1}$ are more stable since they lack a benzyl substituent on the $\mathrm{C} \alpha$. 
Influence of the nature of the substituent in malonic hydroxamic series. Plasma stabilities for malonic compound 1 and analogues 2-4, 6-10 are presented in Table 3. In the malonic series, again, the nature of the substituant on the malonic carbon (e.g. alpha to the hydroxamate function) has a great impact on stability. Indeed, the half-lives range from 0.8 to $33 \mathrm{~h}$. For example, 7 which bears no substituent, displays an intermediate stability of $10.5 \mathrm{~h}$, comparable to that of the glycine derivatives $\mathbf{2 0}$ and $\mathbf{2 1}$ in the previous series. The shortest half-lives were observed for hydroxamic acids 1, 4, 6. Again, as for the previous series, the benzyl substituent appears to be deleterious for the stability as it can be seen when comparing $\mathbf{1}$ and 7, as well as $\mathbf{6}$ and $\mathbf{8}$. In contrast, introduction of a methyl group on the same malonic carbon decreases the susceptibility to hydrolysis (6 vs $\mathbf{1}$ and 8-10 vs 7). Interestingly, in the benzyl series, methylation on the nitrogen of the hydroxamate did not increase stability ( 4 vs 1 and 6).

Electronic and geometric effects. Three $\alpha, \beta$-unsaturated derivatives were prepared and tested ((E)-2,(Z)-2 and 3). The three compounds are more stable than the saturated analogue 1. This improved stability could be attributed to the dispersion of the electrophilic character on two centers. Another explanation could be the influence of steric constraints caused by the insaturation. Indeed, for $\mathbf{2}$, the $\mathrm{Z}$ configuration is much more stable than the $\mathrm{E}$ configuration. This could be due to a better recognition by hydrolases of the extended configuration of (E)-2, or a steric protection of the electrophilic carbonyl by the aromatic ring in (Z)-2. The high stability of $\mathbf{3}$ is probably mainly due to its cyclic nature.

\section{Summary.}


Comparison of half-lives of all direct analogues of phenylpropionohydroxamic acid 14 provides useful information (Table 5). Conformationnally flexible analogues 14, 22, 1 and 11 are globally highly unstable. Compounds (E)-2 and $\mathbf{1 6}$ that unveil the hydroxamate moiety, are more stable than the previous flexible compounds probably due to the less electrophilic carbonyl group vicinal to a double bond. (Z)-2 presents two stabilizing features that are the steric hindrance of the hydroxamate and the less electrophilic carbonyl group. Finally, it is possible that an extended conformation $((\mathbf{E})-\mathbf{2}, \mathbf{1}$ and $\mathbf{1 4})$ of the arylated chain is favourable to the recognition by esterases. A phenylbutanoic ester chain is also found in enalapril which is very rapidly hydrolysed.

We have shown that methylation of the alpha position to the electophilic carbonyl increases in each case the stability. This effect is consistent with the frequent occurrence of neopentyl centers in alpha position to hydroxamic acids developed as lead compounds. However, a highly substituted center is not always required to obtain stable compounds, as we have demonstrated here (SAHA, 7 vs 1). Gilmore et al were surprised that a compound lacking a substituent at the alpha position is as stable as its neopentyl analog. ${ }^{38}$ In our opinion, this stability reflects more the fact that both compounds are devoid of a correctly placed aryl substituent favouring the hydrolysis.

In conclusion, plasma stability of hydroxamates seems to be the result of two opposing factors (Figure 3). Stabilizing factors are the steric hindrance around the hydroxamate group and the mesomeric effects that reduce the electrophilic nature of the carbonyl. Among potential hydrolysis-promoting factors, we have identified hydrophobicity and the presence of an extended phenylpropiono- or phenylbutyro- hydroxamic motif. These results allow us to hypothesize a preliminary pharmacophore for plasma hydrolysis or stability of hydroxamic acids (Figure 3 ). 
In case of significant hydrolysis, it may be interesting to design a prodrug. Only a few prodrugs of hydroxamates are described. ${ }^{28,30}$ Our attempts to protect $\mathbf{1}$ as prodrug $\mathbf{5}$ did not significantly improve the half-life (Table 6). ${ }^{39}$ Prodrug $\mathbf{5}$ is hydrolyzed into $\mathbf{1}$ with a half-life of $0.3 \mathrm{~h}$, and then compound $\mathbf{1}$ is hydrolyzed into the corresponding carboxylic acid in $0.8 \mathrm{~h}$, resulting in an almost unchanged half-life of $\mathbf{1}$.

The result obtained with trans-cinnamic compound $(\mathbf{Z})-\mathbf{2}$ is of high interest in the light of the current development of cinnamic inhibitors of botulinum neurotoxin A or histone deacetylases (Figure 2). ${ }^{40-41}$ For example, the direct analogue of cinnamic acid, belinostat PXD101, is currently evaluated in 18 clinical trials in cancer therapy. ${ }^{42}$

Several papers report species differences for the plasma stability of amides or hydroxamates. ${ }^{43}$ It is known that generally speaking, rat plasma is "more aggressive" than human plasma. ${ }^{23}$ Not surprisingly, independently of their half-lives in rat plasma, all our compounds are very stable in human plasma $\left(\mathrm{t}_{1 / 2}>24 \mathrm{~h}\right)$ (Table 7$)$. The difference in stability in human and rodent plasma remains a specific hurdle in the development of hydroxamates. In fact, hydroxamates must be stable in preclinical in vivo models (often rodents) for proof of concept. In this context, our results help to rationalize structure-stability relationships. These should help medicinal chemists to reconcile the pharmacophore of their target and the structural requirements for rodent plasma stability. 


\section{Experimental section}

\section{Chemistry.}

General Information. 2-Chlorotrityl N-Fmoc-Hydroxylamine, polymer-bound, 100-200 mesh was purchased from Sigma-Aldrich Inc. NMR spectra were recorded on a Bruker DRX-300 spectrometer. Chemical shifts are in parts per million (ppm). The assignments were made using one dimensional (1D) ${ }^{1} \mathrm{H}$ and ${ }^{13} \mathrm{C}$ spectra and two-dimensional (2D) HSQC and COSY spectra. Mass spectra were recorded on a MALDI-TOF Voyager-DE-STR spectrometer, or with a LCMS-MS triple-quadrupole system (Varian 1200ws). The purities of the desired compounds were confirmed by reversed phase HPLC or LCMS, using UV detection (215 nM): HPLC analyses were performed using a C18 TSKGEL Super ODS $2 \mu$ m column (dimensions $50 * 4.6 \mathrm{~mm}$ ). A gradient starting from $100 \% \mathrm{H}_{2} \mathrm{O} / 0.05 \%$ TFA and reaching $20 \% \mathrm{H}_{2} \mathrm{O} / 80 \% \mathrm{CH}_{3} \mathrm{CN} / 0.05 \%$ TFA within $10 \mathrm{~min}$ at a flow rate of $1 \mathrm{~mL} / \mathrm{min}$ was used. LCMS gradient starting from $100 \% \mathrm{H}_{2} \mathrm{O} / 0.1 \%$ formic acid and reaching $20 \% \mathrm{H}_{2} \mathrm{O} / 80 \%$ $\mathrm{CH}_{3} \mathrm{CN} / 0.08 \%$ formic acid within $10 \mathrm{~min}$ at a flow rate of $1 \mathrm{~mL} / \mathrm{min}$ was used. Melting points were measured on a Büchi B-540 apparatus and are uncorrected. All commercial reagents and solvents were used without further purification. Organic layers obtained after extraction of aqueous solutions were dried over $\mathrm{MgSO}_{4}$ and filtered before evaporation in vacuo. Thick layer chromatography was

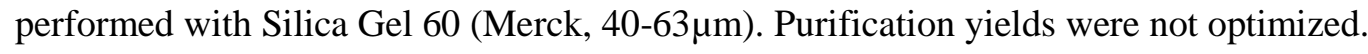

2-Benzyl-N-(4-fluoro-benzyl)-N'-hydroxy-malonamide (1) See Supporting Info; White powder; Yield=88\%; Purity 100\%; NMR ${ }^{1} \mathrm{H}$ DMSO-d6 $\delta$ ppm : 2.96-3.10 (m, 2H), 3.35-3.40 (m, 1H), 4.16 $(\mathrm{dd}, \mathrm{J}=15, \mathrm{~J}=5.7 \mathrm{~Hz}, 1 \mathrm{H}), 4.27(\mathrm{dd}, \mathrm{J}=15, \mathrm{~J}=6 \mathrm{~Hz}, 1 \mathrm{H}), 7.04-7.27(\mathrm{~m}, 9 \mathrm{H}), 8.40(\mathrm{t}, \mathrm{J}=5.6 \mathrm{~Hz}$, NHCO), $8.93(\mathrm{~s}, \mathrm{OH}), 10.58(\mathrm{~s}, \mathrm{CONHO}) ; \mathrm{NMR}{ }^{13} \mathrm{C}$ DMSO-d ${ }_{6} \delta \mathrm{ppm}: 35.0 ; 42.1 ; 52.5 ; 115.5\left(\mathrm{~d}, \mathrm{~J}_{\mathrm{CF}}\right.$ $=21.1 \mathrm{~Hz}) ; 126.8 ; 128.8 ; 129.4 ; 129.5\left(\mathrm{~d}, \mathrm{~J}_{\mathrm{CF}}=8.4 \mathrm{~Hz}\right) ; 136.0\left(\mathrm{~d}, \mathrm{~J}_{\mathrm{CF}}=2.3 \mathrm{~Hz}\right) ; 139.6 ; 161.7\left(\mathrm{~d}, \mathrm{~J}_{\mathrm{CF}}=\right.$ 240.4Hz); 166.3; 168.9. $\operatorname{tr}_{\text {LCMS }} 4.31 \mathrm{~min} ; \mathrm{MS}[\mathrm{M}+\mathrm{H}]^{+} \mathrm{m} / \mathrm{z} 317 ; \mathrm{mp} 193-194{ }^{\circ} \mathrm{C}$.

\section{N-(4-Fluoro-benzyl)-N'-hydroxy-2-[1-phenyl-meth-(Z)-ylidene]-malonamide $\quad((Z)-2) \quad$ See} Supporting Info; White powder; Yield 96\%; purity 99\%; ${ }^{1} \mathrm{H}$ NMR NMR (DMSO-d6) $\delta 4.37$ (d, $J=$ $6.0 \mathrm{~Hz}, 2 \mathrm{H}), 7.12-7.18(\mathrm{~m}, 2 \mathrm{H}), 7.32-7.40(\mathrm{~m}, 5 \mathrm{H}), 7.43(\mathrm{~s}, 1 \mathrm{H}), 7.51-7.54(\mathrm{~m}, 2 \mathrm{H}), 8.26(\mathrm{t}, J=6.0$ 
$\mathrm{Hz}, \mathrm{NHCO}), 9.13$ (s, OH), 11.01 (s, CONHO); NMR ${ }^{13} \mathrm{C}$ DMSO-d 6 $\delta$ ppm : 42.6; $115.6\left(\mathrm{~d}, \mathrm{~J}_{\mathrm{CF}}=21\right.$ $\mathrm{Hz}) ; 129.3 ; 129.5 ; 129.9 ; 130.1 ; 130.6 ; 134.2 ; 136.2 ; 137.3 ; 161.8\left(\mathrm{~d}, \mathrm{~J}_{\mathrm{CF}}=246 \mathrm{~Hz}\right) ; 163.5 ; 164.6$. $\operatorname{tr}_{\text {LCMS }} 4.23 \mathrm{~min} ; \mathrm{MS}[\mathrm{M}+\mathrm{H}]^{+} \mathrm{m} / \mathrm{z} 315$.

2-[1-Phenyl-meth-(Z)-ylidene]-malonic acid monoethyl ester ((E)-2). See Supporting Info; White powder. Yield 70\%; Purity 95\%; NMR ${ }^{1} \mathrm{H}$ DMSO-d6 $\delta$ ppm : 4.30 (d, J = 6.0 Hz, 2H), 7.08-7.37 (m, $10 \mathrm{H}) ; 8.86\left(\mathrm{t}, \mathrm{J}=6.0 \mathrm{~Hz}, \mathrm{NHCO}\right.$ ), 9.08 (br s, OH), 10.70 (br s, CONHO); $\operatorname{tr}_{\mathrm{LCMS}} 4.41 \mathrm{~min}$; MS $[\mathrm{M}+\mathrm{H}]^{+} \mathrm{m} / \mathrm{z} 315$.

1-Hydroxy-2-oxo-1,2-dihydro-quinoline-3-carboxylic acid 4-fluoro-benzylamide (3). See Supporting Info; Beige powder (70\%); Purity 99\%; ${ }^{1} \mathrm{H}$ NMR (DMSO-d6) $\delta$ ppm : 4.58 (d, J=6.0 Hz, 2H); 7.14-7.20 (m, 2H), 7.38-7.41 (m, 3H), 7.76-7.81 (m, 2H), $8.05(\mathrm{~d}, \mathrm{~J}=7.5 \mathrm{~Hz}, 1 \mathrm{H}), 8.85(\mathrm{~s}, 1 \mathrm{H})$, $10.06(\mathrm{t}, \mathrm{J}=6.0 \mathrm{~Hz}, \mathrm{NH}), 11.82(\mathrm{~s}, 1 \mathrm{H}, \mathrm{OH}) ; \mathrm{NMR}{ }^{13} \mathrm{C}$ DMSO-d $\mathrm{d}_{6} \delta \mathrm{ppm}: 42.5 ; 113.2 ; 115.8\left(\mathrm{~d}, \mathrm{~J}_{\mathrm{CF}}=\right.$ $21 \mathrm{~Hz}) ; 118.4 ; 121.9 ; 123.9 ; 130.0\left(\mathrm{~d}, \mathrm{~J}_{\mathrm{CF}}=8 \mathrm{~Hz}\right) ; 130.8 ; 134.0 ; 135.9 ; 139.7 ; 141.4 ; 158.1 ; 161.9(\mathrm{~d}$, $\left.\mathrm{J}_{\mathrm{CF}}=240 \mathrm{~Hz}\right) ; 163.1 ; \operatorname{tr}_{\mathrm{LCMS}} 5.10 \mathrm{~min} ; \mathrm{MS}[\mathrm{M}+\mathrm{H}]^{+} \mathrm{m} / \mathrm{z} 313$.

\section{2-Benzyl- $N$-(4-fluoro-benzyl)- $N$ '-hydroxy- $N^{\prime}$-méthyl-malonamide (4) 2-Benzyl-malonic acid} diethyl ester (7.5 g, $30 \mathrm{mmol})$ was added to a solution of $\mathrm{KOH}(1.68 \mathrm{~g}, 30 \mathrm{mmol})$ in EtOH $(45 \mathrm{~mL})$. The solution was stirred at room temperature for $6 \mathrm{~h}$ and evaporated. The residue was dissolved in $\mathrm{NaHCO}_{3} 5 \%(20 \mathrm{~mL})$ and extracted with ethyl acetate. The aqueous layer was acidified and extracted 3 times with ethyl acetate. The combined organic layers were dried over $\mathrm{MgSO}_{4}$, filtered and evaporated to give (4a) as a colorless oil (86\%). Purity 99\%; ${ }^{1} \mathrm{H}$ NMR (DMSO-d6) $\delta 1.23(\mathrm{t} ; J=7.2$ $\mathrm{Hz} ; 3 \mathrm{H}) ; 3.26(\mathrm{~d} ; J=7.8 \mathrm{~Hz} ; 2 \mathrm{H}) ; 3.73(\mathrm{t} ; \mathrm{J}=7.8 \mathrm{~Hz} ; 1 \mathrm{H}) ; 4.19(\mathrm{q} ; J=7.2 \mathrm{~Hz} ; 2 \mathrm{H}) ; 7.23-7.34$ (m; $5 \mathrm{H}) ; 10.11(\mathrm{~s} ; 1 \mathrm{H} ; \mathrm{COOH}) . \mathrm{MS}[\mathrm{M}+\mathrm{H}]^{+} \mathrm{m} / \mathrm{z}$ 223. 2-benzyl-malonic acid monoethyl ester (4a) (7.556 g, $34 \mathrm{mmol}$ ) was dissolved in DMF (25 mL) and DIEA (7.1 mL, $41 \mathrm{mmol})$. CDI (6.06 g, $37.4 \mathrm{mmol})$ was dissolved in THF (50 mL) and added to the carboxylic acid solution. The reaction mixture was stirred at room temperature for $1.5 \mathrm{~h}$ and 4-fluorobenzylamine $(3.872 \mathrm{~mL}, 34 \mathrm{mmol})$ dissolved in DMF $(40 \mathrm{~mL})$ and DIEA $(11.8 \mathrm{~mL}, 68 \mathrm{mmol})$ was added. The solution was stirred at room temperature for 
$3 \mathrm{~h}$ and evaporated. The crude product was dissolved in ethyl acetate, washed 10 times with $\mathrm{H}_{2} \mathrm{O}, 3$ times with $\mathrm{KHSO}_{4}$ solution $(\mathrm{pH}=3$ ) and with aq. $\mathrm{NaCl}$, dried over $\mathrm{MgSO} 4$, filtered and evaporated to give the ester as a beige powder (81\%). Purity 95\%; ${ }^{1} \mathrm{H}$ NMR (DMSO-d6) $\delta 1.14(\mathrm{t} ; J=7.2 \mathrm{~Hz} ; 3 \mathrm{H})$; 3.04-3.10 (m; 2H); $3.69(\mathrm{dd} ; J=6.6 \mathrm{~Hz} ; J=9.0 \mathrm{~Hz} ; 1 \mathrm{H}) ; 4.08(\mathrm{q} ; J=7.2 \mathrm{~Hz} ; 2 \mathrm{H}) ; 4.19-4.23(\mathrm{~m}$, 2H), 7.05-7.09 (m; 4H); 7.19-7.28 (m; 5H); 8,60 (t; $J=5.4 \mathrm{~Hz} ; \mathrm{NH}) ; \operatorname{tr}_{\text {LCMS }} 6.02 \mathrm{~min} ; \mathrm{MS}[\mathrm{M}+\mathrm{H}]^{+} \mathrm{m} / \mathrm{z}$ 330. The ester $(8.88 \mathrm{~g}, 27 \mathrm{mmol})$ was added to a solution of $\mathrm{KOH}(4.54 \mathrm{~g}, 81 \mathrm{mmol})$ in EtOH (50 $\mathrm{mL}$ ). The solution was stirred at room temperature overnight and evaporated. The residue was dissolved in $\mathrm{H}_{2} \mathrm{O}(20 \mathrm{~mL})$ and extracted with ethyl acetate. The aqueous layer was acidified and extracted 3 times with ethyl acetate. The combined organic layers were dried over $\mathrm{MgSO}_{4}$, filtered and evaporated to give (4b) as a white powder (80\%). Purity 99\%; ${ }^{1} \mathrm{H}$ NMR (DMSO-d6) $\delta$ 2.96-3.09 (m; 2H); $3.60(\mathrm{dd} ; \mathrm{J}=6.3 \mathrm{~Hz} ; \mathrm{J}=9.3 \mathrm{~Hz} ; 1 \mathrm{H}) ; 4.11(\mathrm{dd} ; J=5.4 \mathrm{~Hz} ; J=15.3 \mathrm{~Hz} ; 1 \mathrm{H}) ; 4.11(\mathrm{dd} ; J=6.3$ $\mathrm{Hz} ; J=15.3 \mathrm{~Hz} ; 1 \mathrm{H}) ; 6.97-7.06(\mathrm{~m} ; 4 \mathrm{H}) ; 7.16-7.29(\mathrm{~m} ; 5 \mathrm{H}) ; 8.53(\mathrm{t} ; J=6.0 \mathrm{~Hz} ; \mathrm{NHCO}) ; 12.61(\mathrm{~s} ;$ 1H; $\mathrm{COOH}$ ). $\operatorname{tr}_{\mathrm{LCMS}} 4.93 \mathrm{~min} ; \mathrm{MS}[\mathrm{M}+\mathrm{H}]^{+} \mathrm{m} / \mathrm{z}$ 302. 2-benzyl-N-(4-fluoro-benzyl)-malonamic acid (4b) was dissolved in DMF (4 mL) and DIEA (1,2 eq ; 0,96 mmol) and PyBrop (0,96 mmol; $124 \mathrm{mg})$ were added. The solution was stirred at room temperature for $1 \mathrm{~min}$ and $N$-methylhydroxylamine. $\mathrm{HCl}$ in DMF (4 mL) and DIEA $(2,4 \mathrm{eq} ; 332 \mu \mathrm{L})$ was added. The solution was stirred at room temperature overnight and evaporated. The residue was dissolved in ethyl acetate and washed 3 times with aq. $\mathrm{NaHCO}_{3} 5 \%$ and once with aq. $\mathrm{NaCl}$, dried over MgSO 4 , filtered and evaporated. The residue was purified by TLC (DCM/MeOH 96/4) to give (4) as a white powder (40\%). Purity 99\%; ${ }^{1} \mathrm{H}$ NMR $($ DMSO-d6) $\delta 2.95(\mathrm{dd} ; \mathrm{J}=7.1 \mathrm{~Hz} ; \mathrm{J}=13.6 \mathrm{~Hz} ; 1 \mathrm{H}) ; 3.07(\mathrm{~s} ; 3 \mathrm{H}) ; 3.04-3.11(\mathrm{~m} ; 1 \mathrm{H}) ; 4.03(\mathrm{t} ; J=7.0$ $\mathrm{Hz} ; 1 \mathrm{H}) ; 4.16(\mathrm{dd} ; J=5.7 \mathrm{~Hz} ; J=15.3 \mathrm{~Hz} ; 1 \mathrm{H}) ; 4.27(\mathrm{dd} ; J=6.1 \mathrm{~Hz} ; J=15.1 \mathrm{~Hz} ; 1 \mathrm{H}) ; 7.05-7.27(\mathrm{~m}$; $9 \mathrm{H}) ; 8.32(\mathrm{~s} ; \mathrm{NH}) ; 9.93(\mathrm{~s} ; \mathrm{OH}) ; \mathrm{NMR}{ }^{13} \mathrm{C}$ DMSO- $d 6 \delta \mathrm{ppm}: 35.1 ; 36.5 ; 41.9 ; 51.1 ; 115.3\left(\mathrm{~d}, J_{\mathrm{CF}}=\right.$ $21.1 \mathrm{~Hz}) ; 126.5 ; 128.5 ; 129.3 ; 129.4 ; 136.0 ; 140.1 ; 161.5\left(\mathrm{~d}, J_{\mathrm{CF}}=241.7 \mathrm{~Hz}\right) ; 169.2 ; 169.4 . \mathrm{t}_{\mathrm{R}}$ LCMS 4.69 $\min ; \mathrm{MS}[\mathrm{M}+\mathrm{H}]^{+} \mathrm{m} / \mathrm{z} 331$.

2-(5,5-Dimethyl-[1,4,2]dioxazol-3-yl)-N-(4-fluoro-benzyl)-3-phenyl-propionamide (5) 2-BenzylN-(4-fluoro-benzyl)-N'-hydroxy-malonamide (1) (1.00 g, $3.16 \mathrm{mmol})$ was dissolved in DCM (100 $\mathrm{mL})$ and 2,2-diethoxypropane (1.528 mL, $9.48 \mathrm{mmol})$ and camphorsulfonic acid (734 mg, $3.16 \mathrm{mmol})$ 
were added. The reaction mixture was stirred at room temperature for $2 \mathrm{~h}$ and aq. $\mathrm{Na}_{2} \mathrm{CO}_{3}$ solution (20 $\mathrm{mL}$ ) was added. The aqueous layer was extracted 4 times with diethyl ether. The combined organic layers were dried over $\mathrm{MgSO}_{4}$, filtered, and evaporated. The residue was dissolved in dioxane ( $\left.8 \mathrm{~mL}\right)$ and $0.1 \mathrm{~N} \mathrm{NaOH}$ solution $(8 \mathrm{~mL})$ was added. The reaction mixture was stirred at room temperature for 3.5h, water was added and reaction mixture was extracted 3 times with ethyl acetate. The combined organic layers were dried over $\mathrm{MgSO}_{4}$, filtered, and evaporated. The residue was purified by TLC (DCM/MeOH 96/4 to give (5) as a white powder (50\%) purity 96\%; ${ }^{1} \mathrm{H}$ NMR NMR $\left(\mathrm{CDCl}_{3}\right) \delta 1.44$ $(\mathrm{s} ; 3 \mathrm{H}) ; 1.46(\mathrm{~s} ; 3 \mathrm{H}) ; 3.11(\mathrm{dd} ; J=8.1 ; \mathrm{J}=13.8 \mathrm{~Hz} ; 1 \mathrm{H}) ; 3.30(\mathrm{dd} ; J=7.2 ; J=14.1 \mathrm{~Hz} ; 1 \mathrm{H}) ; 3.60(\mathrm{t} ; J$ $=7.8 \mathrm{~Hz} ; 1 \mathrm{H}) ; 4.32-4.38(\mathrm{~m} ; 2 \mathrm{H}) ; 6.78(\mathrm{br} \mathrm{s} ; \mathrm{NH}) ; 6.90-6.96(\mathrm{~m} ; 2 \mathrm{H}) ; 7.06-7.10(\mathrm{~m} ; 2 \mathrm{H}) ; 7.17-7.26$ $(\mathrm{m} ; 5 \mathrm{H}) ; \operatorname{tr}_{\text {LCMS }} 6.20 \mathrm{~min} ; \mathrm{MS}[\mathrm{M}+\mathrm{H}]^{+} \mathrm{m} / \mathrm{z} 357$.

2-Benzyl-N-(4-fluoro-benzyl)-N'-hydroxy-2-methyl-malonamide (6) Sodium (633 mg, 27.5 mmol) was added slowly to absolute EtOH $(30 \mathrm{~mL})$ at $0{ }^{\circ} \mathrm{C}$. The solution was stirred at room temperature for $30 \mathrm{~min}$ and diethylmethylmalonate $(4.30 \mathrm{~mL}, 25 \mathrm{mmol})$ was added. The reaction mixture was stirred at $50{ }^{\circ} \mathrm{C}$ for $1 \mathrm{~h}$ and benzylbromide $(2.392 \mathrm{~mL}, 20 \mathrm{mmol})$ was added. The reaction mixture was stirred at $50{ }^{\circ} \mathrm{C}$ for $2 \mathrm{~h}$ and evaporated. The residue was dissolved in DCM and washed 3 times with aq. $\mathrm{NaHCO}_{3} 5 \%$, once with $\mathrm{NaOH}$ solution $(1 \mathrm{~N})$ and with $\mathrm{H}_{2} \mathrm{O}$, dried over $\mathrm{MgSO}_{4}$, filtered and evaporated to give 2-benzyl-2-methyl-malonic acid diethyl ester (6a) as a colorless oil (83\%). Purity 95\%; ${ }^{1} \mathrm{H}$ NMR $\left(\mathrm{CD}_{2} \mathrm{Cl}_{2}\right) \delta 1.27(\mathrm{t} ; J=7.2 \mathrm{~Hz} ; 6 \mathrm{H}) ; 1.32(\mathrm{~s} ; 3 \mathrm{H}) ; 3.22(\mathrm{~s} ; 2 \mathrm{H}) ; 4.20(\mathrm{q} ; J=7.2 \mathrm{~Hz}$; 4H); 7.13-7.16 (m; 2H); 7.23-7.33 (m;3H); $\operatorname{tr}_{\mathrm{LCMS}} 6.93 \mathrm{~min} ; \mathrm{MS}[\mathrm{M}+\mathrm{Na}]^{+} \mathrm{m} / \mathrm{z} 287$. Diester (6a) (3.854 g, $14.6 \mathrm{mmol})$ was added to a solution of $\mathrm{KOH}(819 \mathrm{mg}, 14.6 \mathrm{mmol})$ in EtOH $(50 \mathrm{~mL})$. The solution was stirred at room temperature for $4 \mathrm{~h}$ and evaporated. The residue was dissolved in $\mathrm{NaHCO}_{3}$ $5 \%$ solution $(20 \mathrm{~mL})$ and washed with DCM. The aqueous layer was acidified and extracted 3 times with DCM. The combined organic layers were dried over $\mathrm{MgSO}_{4}$, filtered and evaporated to give 2benzyl-2-methyl-malonic acid monoethyl ester as a white powder $(80 \%)$. Purity $97 \%$; ${ }^{1} \mathrm{H}$ NMR $\left(\mathrm{CD}_{2} \mathrm{Cl}_{2}\right) \delta: 1.30(\mathrm{t} ; J=7.2 \mathrm{~Hz} ; 3 \mathrm{H}) ; 1.43(\mathrm{~s} ; 3 \mathrm{H}) ; 3.21(\mathrm{~d} ; \mathrm{J}=13.5 \mathrm{~Hz} ; 1 \mathrm{H}) ; 3.32(\mathrm{~d} ; J=13.5 \mathrm{~Hz}$; 1H); $4.23(\mathrm{q} ; J=7.2 \mathrm{~Hz} ; 2 \mathrm{H}) ; 7.17-7.20(\mathrm{~m} ; 2 \mathrm{H}) ; 7.28-7.35(\mathrm{~m} ; 3 \mathrm{H}) ; \mathrm{MS}[\mathrm{M}-\mathrm{H}]^{-} \mathrm{m} / \mathrm{z} 235$. 
2-benzyl-2-methyl-malonic acid monoethyl ester $(8.2 \mathrm{mmol}$,) was dissolved in DMF $(20 \mathrm{~mL})$ and DIEA (4.966 mL, $28.7 \mathrm{mmol})$. EDCI (1.895 g, $9.8 \mathrm{mmol})$ and HOBt (1.505 g, $9.8 \mathrm{mmol})$ were added, the solution was stirred for $5 \mathrm{~min}$ and 4-fluorobenzylamine (942 $\mu \mathrm{L}, 8.2 \mathrm{mmol})$ was added. The solution was stirred at room temperature overnight and evaporated. The residue was dissolved in ethyl acetate and washed 4 times with aq. $\mathrm{NaHCO}_{3} 5 \%$ and once with $1 \mathrm{~N} \mathrm{HCl}$ solution, and once with aq. $\mathrm{NaCl}$, dried over $\mathrm{MgSO}_{4}$, filtered and evaporated to give 2-benzyl-N-(4-fluoro-benzyl)-2-methylmalonamic acid ethyl ester as a white powder (66\%). Purity 98\%; ${ }^{1} \mathrm{H}$ NMR (DMSO-d6) $\delta 1.14$ (t; J = $7.2 \mathrm{~Hz} ; 3 \mathrm{H}) ; 1.21(\mathrm{~s} ; 3 \mathrm{H}) ; 3.10(\mathrm{~d} ; \mathrm{J}=13.2 \mathrm{~Hz} ; 1 \mathrm{H}) ; 3.17(\mathrm{~d} ; \mathrm{J}=13.2 \mathrm{~Hz} ; 1 \mathrm{H}) ; 4.08(\mathrm{q} ; \mathrm{J}=7.2 \mathrm{~Hz}$ $2 \mathrm{H}) ; 4.18-4.32(\mathrm{~m} ; 2 \mathrm{H}) ; 7.06-7.28(\mathrm{~m} ; 9 \mathrm{H}) ; 8.33(\mathrm{t} ; \mathrm{J}=6.0 \mathrm{~Hz} ; \mathrm{NH}) ; \operatorname{tr}_{\mathrm{LCMS}} 6.58 \mathrm{~min} ; \mathrm{MS}[\mathrm{M}+\mathrm{H}]^{+} \mathrm{m} / \mathrm{z}$ 344. Ester (3.8 mmol) was added to a solution of $\mathrm{KOH}(6.405 \mathrm{~g}, 11.4 \mathrm{mmol})$ in EtOH $(9 \mathrm{~mL})$. The solution was stirred at room temperature overnight and evaporated. The residue was dissolved in $\mathrm{H}_{2} \mathrm{O}$ and washed with DCM. The aqueous layer was acidified and extracted 3 times with DCM. The combined organic layers were dried over $\mathrm{MgSO}_{4}$, filtered and evaporated to give 2-benzyl-N-(4fluoro-benzyl)-2-methyl-malonamic acid as a beige powder (84\%). Purity 95\%; ${ }^{1} \mathrm{H} \mathrm{NMR}\left(\mathrm{CD}_{2} \mathrm{Cl}_{2}\right) \delta$ $1.86(\mathrm{~s} ; 3 \mathrm{H}) ; 3.06$ (d; J = 13.2 Hz; 1H); $3.16(\mathrm{~d} ; \mathrm{J}=13.2 \mathrm{~Hz} ; 1 \mathrm{H}) ; 4.25$ (d; J = $6.0 \mathrm{~Hz} ; 2 \mathrm{H}) ; 7.07-7.26$ (m; 9H); $8.30(\mathrm{t} ; \mathrm{J}=6.0 \mathrm{~Hz} ; \mathrm{NH}) ; \mathrm{t}_{\mathrm{R}}$ LCMS $5.40 \mathrm{~min} ; \mathrm{MS}[\mathrm{M}+\mathrm{H}]^{+} \mathrm{m} / \mathrm{z} 316$. Acid (317 mg, $\left.1 \mathrm{mmol}\right)$ was dissolved in DCM (8 mL) and TEA (155 $\mu \mathrm{L} ; 1.1 \mathrm{mmol})$. Ethyl chloroformate (105 $\mu \mathrm{L} ; 1.1 \mathrm{mmol})$ was added dropwise at $0{ }^{\circ} \mathrm{C}$, the solution was stirred for $40 \mathrm{~min}$ at $0{ }^{\circ} \mathrm{C}$. and O-tritylhydroxylamine (206 $\mathrm{mg} ; 0.75 \mathrm{mmol})$ in DCM $(2 \mathrm{~mL})$ was added. The solution was stirred at room temperature for $1 \mathrm{~h}$ and evaporated. The residue was dissolved in ethyl acetate and washed 4 times with aq. $\mathrm{NaHCO}_{3} 5 \%$ and once with $1 \mathrm{~N} \mathrm{HCl}$ solution, and once with aq. $\mathrm{NaCl}$, dried over $\mathrm{MgSO}_{4}$, filtered and evaporated. The crude product was purified by TLC (DCM/MeOH 98/2) to give 2-benzyl-N-(4-fluoro-benzyl)-2methyl-N'-trityloxy-malonamide as a white powder (60\%). Purity 98\%; ${ }^{1} \mathrm{H}$ NMR (DMSO-d6) $\delta 0.95$ $(\mathrm{s} ; 3 \mathrm{H}) ; 2.65(\mathrm{~d} ; \mathrm{J}=13.5 \mathrm{~Hz} ; 1 \mathrm{H}) ; 3.03(\mathrm{~d} ; \mathrm{J}=13.5 \mathrm{~Hz} ; 1 \mathrm{H}) ; 4.14(\mathrm{~d} ; \mathrm{J}=5.7 \mathrm{~Hz} ; 2 \mathrm{H}) ; 6.83-6.85$ (m; 2H); 7.04-7.15 (m; 7H); $7.33(\mathrm{~s} ; 15 \mathrm{H}) ; 8.21(\mathrm{t} ; \mathrm{J}=5.7 \mathrm{~Hz} ; \mathrm{NH}) ; 10.13(\mathrm{~s} ; \mathrm{CONHO}) ; \operatorname{tr}_{\mathrm{LCMS}} 8.59 \mathrm{~min}$; MS $[\mathrm{M}-\mathrm{H}]^{-} \mathrm{m} / \mathrm{z}$ 571. The protected hydroxamic acid (239 mg; $0.4 \mathrm{mmol}$ ) was dissolved in TFA 2\%/DCM (0.03 M), and triisopropylsilane was added dropwise until the yellow color disappeared. The reaction mixture was stirred $5 \mathrm{~min}$ at room temperature, solvents were removed under reduced 
pressure, and the residue was washed with petroleum ether and purified by TLC (DCM/MeOH/TEA 6/1.5/2.5) to give (6) as a beige powder (60\%). Purity 99\%; ${ }^{1} \mathrm{H}$ NMR $\left(\mathrm{CD}_{2} \mathrm{Cl}_{2}\right) \delta: 1.24(\mathrm{~s} ; 3 \mathrm{H}) ; 2.99(\mathrm{~s}$; $2 \mathrm{H}) ; 4.34(\mathrm{~s} ; 2 \mathrm{H}) ; 7.00-7.23(\mathrm{~m} ; 9 \mathrm{H}) . \mathrm{NMR}{ }^{13} \mathrm{C} \mathrm{CDCl}_{3} \delta \mathrm{ppm}: 17.8 ; 43.3 ; 44.8 ; 53.1 ; 115.5\left(\mathrm{~d}, J_{\mathrm{CF}}=\right.$ $21.3 \mathrm{~Hz}) ; 127.2 ; 128.4 ; 129.5\left(\mathrm{~d}, J_{\mathrm{CF}}=7.5 \mathrm{~Hz}\right) ; 130.0 ; 133.2 ; 135.4 ; 162.2\left(\mathrm{~d}, J_{\mathrm{CF}}=244.4 \mathrm{~Hz}\right) ; 170.1 ;$ 172.1. $\operatorname{tr}_{\text {LCMS }} 4.66 \mathrm{~min} ; \mathrm{MS}[\mathrm{M}+\mathrm{H}]^{+} \mathrm{m} / \mathrm{z} 331$.

$N$-(4-Fluoro-benzyl)- $N^{\prime}$-hydroxy-malonamide (7) : O-tritylhydroxylamine (468 mg, $1.7 \mathrm{mmol}$ ) was dissolved in DCM (10 mL) and DIEA (346 $\mu \mathrm{L}, 2 \mathrm{mmol})$ was added. The flask was put in an ice bath and chlorocarbonylacetic acid ethyl ester $(2 \mathrm{mmol}, 253 \mu \mathrm{L})$ was added dropwise. Reaction mixture was stirred at room temperature for $3 \mathrm{~h}$ and washed with aq. NaHCO3 5\% (6 times) and once with aq. $\mathrm{NaCl}$, dried over $\mathrm{MgSO}_{4}$, filtered and evaporated. The residue was washed with petroleum ether to give N-Trityloxy-malonamic acid ethyl ester as a white powder (79\%) Purity 99\%; ${ }^{1} \mathrm{H}$ NMR (DMSOd6) $\delta$ ppm : $1.10(\mathrm{t} ; \mathrm{J}=7.2 \mathrm{~Hz} ; 3 \mathrm{H}) ; 2.94(\mathrm{~s} ; 2 \mathrm{H}) ; 3.97(\mathrm{q} ; \mathrm{J}=7.2 \mathrm{~Hz} ; 2 \mathrm{H}) ; 7.32(\mathrm{~s} ; 15 \mathrm{H}) ; 10.47(\mathrm{~s}$; $\mathrm{NH}) ; \operatorname{tr}_{\text {LCMS }} 5.10 \mathrm{~min} ; \mathrm{MS}(\mathrm{M}-\mathrm{H})^{-} \mathrm{m} / \mathrm{z}$ 388. N-Trityloxy-malonamic acid ethyl ester (468 mg, 1.2 mmol) was dissolved in DCM (7mL) and $\mathrm{KOH}(202 \mathrm{mg}, 3.6 \mathrm{mmol})$ was added as a solution in EtOH $(10 \mathrm{~mL})$. The reaction mixture was stirred at room temperature overnight and evaporated. The residue was dissolved in $\mathrm{H}_{2} \mathrm{O}$ and washed with DCM (3 times). The aqueous layer was acidified by $\mathrm{KHSO}_{4}$ $(\mathrm{pH}=6)$ and extracted with DCM (4 times). The combined organic layers were dried over $\mathrm{MgSO}_{4}$, filtered and evaporated to give N-Trityloxy-malonamic acid as a white powder $(90 \%)$ Purity $98 \% ;{ }^{1} \mathrm{H}$ NMR (DMSO-d6) $\delta$ ppm: $2.84(\mathrm{~s} ; 2 \mathrm{H}) ; 7.32(\mathrm{~s} ; 15 \mathrm{H}) ; \operatorname{tr}_{\text {LCMS }} 5.68 \mathrm{~min} ; \mathrm{MS}[\mathrm{M}-\mathrm{H}]^{-} \mathrm{m} / \mathrm{z}$ 360. Acid (360 mg, $1 \mathrm{mmol})$ was dissolved in DMF (10mL) and DIEA (346 $\mu \mathrm{L}, 2 \mathrm{mmol})$, EDCI (210 mg, 1.1 mmol) and HOBt $(168 \mathrm{mg}, 1.1 \mathrm{mmol})$ were added. The reaction mixture was stirred at room temperature for $5 \mathrm{~min}$ and 4-fluorobenzylamine $(115 \mu \mathrm{L}, 1 \mathrm{mmol})$ was added. The reaction mixture was stirred at room temperature overnight and evaporated. The crude product was dissolved in DCM, washed 3 times with $5 \%$ aq. $\mathrm{NaHCO}_{3}$ and once with aq. $\mathrm{NaCl}$, dried over $\mathrm{MgSO}_{4}$, filtered and evaporated. The residue was washed with petroleum ether to give $N$-(4-Fluoro-benzyl)- $N$-trityloxymalonamide as a white powder (85\%) Purity 95\%; ${ }^{1} \mathrm{H}$ NMR (DMSO-d6) $\delta$ ppm: $2.72(\mathrm{~s} ; 2 \mathrm{H}) ; 4.15$ (d; 
$\mathrm{J}=6.0 \mathrm{~Hz} ; 2 \mathrm{H}) ; 7.07-7.31(\mathrm{~m} ; 19 \mathrm{H}) ; 8.68($ br s; $1 \mathrm{H}, \mathrm{NHCO}) ; 10.43$ (br s; $1 \mathrm{H} ; \mathrm{CONHO}) . \operatorname{tr}_{\mathrm{LCMS}} 6.85$ $\min ;$ MS [M-H]- m/z 467. The protected hydroxamic acid (190 mg; $0.4 \mathrm{mmol})$ was dissolved in TFA 2\%/DCM (0.03 M), and triisopropylsilane was added dropwise until the yellow color disappeared. The reaction mixture was stirred $5 \mathrm{~min}$ at room temperature, solvents were removed under reduced pressure, and the residue was washed with petroleum ether to give (7) as a beige powder (90\%). Purity 97\%; ${ }^{1} \mathrm{H}$ NMR (DMSO-d6) $\delta 2.95(\mathrm{~s} ; 2 \mathrm{H}) ; 4.26(\mathrm{~d} ; \mathrm{J}=5.4 \mathrm{~Hz} ; 2 \mathrm{H}) ; 7.10-7.16(\mathrm{~m} ; 2 \mathrm{H}) ; 7.29-7.33(\mathrm{~m}$; 2H); 8.51 (br s; NHCO); 8.93 (br s; OH); 10.56 (s; CONHO); NMR ${ }^{13} \mathrm{C}$ DMSO-d6 $\delta$ ppm : 41.3, 41.9, $115.5\left(\mathrm{~d}, \mathrm{~J}_{\mathrm{CF}}=21.7 \mathrm{~Hz}\right), 129.5\left(\mathrm{~d}, \mathrm{~J}_{\mathrm{CF}}=7.8 \mathrm{~Hz}\right) ; 135.9 ; 138.1 ; 161.6\left(\mathrm{~d}, \mathrm{~J}_{\mathrm{CF}}=239.2 \mathrm{~Hz}\right) ; 164.2 ; 166.9$. $\operatorname{tr}_{\text {LCMS }} 2.81 \mathrm{~min} ; \mathrm{MS}[\mathrm{M}+\mathrm{H}]^{+} \mathrm{m} / \mathrm{z} 227$.

N-(4-Fluoro-benzyl)-N'-hydroxy-2-methyl-malonamide (8): 2-Methyl-malonic acid diethyl ester $(871 \mathrm{mg}, 5 \mathrm{mmol})$ was dissolved in $\mathrm{EtOH}(20 \mathrm{~mL})$ and $\mathrm{KOH}(280 \mathrm{mg}, 5 \mathrm{mmol})$ was added. The reaction mixture was stirred at room temperature for $4 \mathrm{~h}$ and evaporated. The residue was dissolved in aq. $5 \% \mathrm{NaHCO}_{3}$ solution and washed with DCM (5 times). The aqueous layer was acidified $(\mathrm{pH}=1)$ and extracted with DCM (4 times). The combined organic layers were dried over $\mathrm{MgSO}_{4}$, filtered and evaporated to give 2-Methyl-malonic acid monoethyl ester as a white powder (71\%) Purity $98 \% ;{ }^{1} \mathrm{H}$ $\operatorname{NMR}\left(\mathrm{CDCl}_{3}\right) \delta$ ppm: $1.29(\mathrm{t} ; \mathrm{J}=7.2 \mathrm{~Hz} ; 3 \mathrm{H}) ; 1.46(\mathrm{~d} ; \mathrm{J}=7.5 \mathrm{~Hz} ; 3 \mathrm{H}) ; 3.47(\mathrm{q} ; \mathrm{J}=7.5 \mathrm{~Hz} ; 1 \mathrm{H}) ; 4.22$ (q; J = 7.2 Hz; 2H); 8.88 (br s; COOH). Acid (518 mg, $3.5 \mathrm{mmol}$ ) was dissolved in DMF (10mL) and DIEA (2.12 mL, $12.2 \mathrm{mmol})$, EDCI (805 mg, $4.2 \mathrm{mmol})$ and HOBt (643 mg, $4.2 \mathrm{mmol})$ were added. The reaction mixture was stirred at room temperature for $5 \mathrm{~min}$ and 4-fluorobenzylamine $(402 \mu \mathrm{L}, 3.5$ mmol) was added. The reaction mixture was stirred at room temperature overnight and evaporated. The crude product was dissolved in DCM, washed 3 times with aq. $\mathrm{NaHCO}_{3} 5 \%$ and once with aq. $\mathrm{NaCl}$, dried over $\mathrm{MgSO} 4$, filtered and evaporated. The residue was washed with petroleum ether to give N-(4-Fluoro-benzyl)-2-methyl-malonamic acid ethyl ester as a white powder (75\%). Purity 95\%; ${ }^{1} \mathrm{H}$ NMR $\left(\mathrm{CD}_{2} \mathrm{Cl}_{2}\right) \delta$ ppm: $1.27(\mathrm{t} ; \mathrm{J}=7.2 \mathrm{~Hz} ; 3 \mathrm{H}) ; 1.43(\mathrm{~d} ; \mathrm{J}=7.2 \mathrm{~Hz} ; 3 \mathrm{H}) ; 3.33(\mathrm{q} ; \mathrm{J}=7.2 \mathrm{~Hz} ; 1 \mathrm{H})$; 4.19 (q; J = 7.2 Hz; 2H); $4.38(\mathrm{dd} ; \mathrm{J}=6.0 \mathrm{~Hz} ; \mathrm{J}=15.0 \mathrm{~Hz} ; 1 \mathrm{H}) ; 4.47(\mathrm{dd} ; \mathrm{J}=6.0 \mathrm{~Hz} ; 15.0 \mathrm{~Hz} ; 1 \mathrm{H})$; 6.73 (br s; NH); 7.02-7.10 (m; 2H); 7.25-7.31 (m; 2H); $\operatorname{tr}_{\mathrm{LCMS}} 4.52 \mathrm{~min} ; \mathrm{MS}[\mathrm{M}+\mathrm{Na}]^{+} \mathrm{m} / \mathrm{z}$ 276. Ester (659 mg, $2.6 \mathrm{mmol})$ was dissolved in $\mathrm{EtOH}(10 \mathrm{~mL})$ and $\mathrm{KOH}(440 \mathrm{mg}, 7.8 \mathrm{mmol})$ was added. The 
reaction mixture was stirred at room temperature overnight and evaporated. The residue was dissolved in $\mathrm{H}_{2} \mathrm{O}$ and washed with DCM (3 times). The aqueous layer was acidified $(\mathrm{pH}=1)$ and extracted with DCM (4 times). The combined organic layers were dried over $\mathrm{MgSO}_{4}$, filtered and evaporated to give $\mathrm{N}$-(4-Fluoro-benzyl)-2-methyl-malonamic acid as a white powder (45\%) Purity $99 \%$; ${ }^{1} \mathrm{H}$ NMR (DMSO-d 6 ) $\delta$ ppm: : $1.19(\mathrm{~d} ; \mathrm{J}=7.2 \mathrm{~Hz} ; 3 \mathrm{H}) ; 3.32(\mathrm{q} ; \mathrm{J}=7.2 \mathrm{~Hz} ; 1 \mathrm{H}) ; 4.22(\mathrm{dd} ; \mathrm{J}=6.0 \mathrm{~Hz} ; 15.3 \mathrm{~Hz}$; 1H); $4.30(\mathrm{dd} ; \mathrm{J}=6.0 \mathrm{~Hz} ; 15.3 \mathrm{~Hz} ; 1 \mathrm{H}) ; 7.10-7.18(\mathrm{~m} ; 2 \mathrm{H}) ; 7.27-7.31(\mathrm{~m} ; 2 \mathrm{H}) ; 8.58(\mathrm{t} ; \mathrm{J}=6.0 \mathrm{~Hz}$; $\mathrm{NH}$ ); 12.49 (br s; $\mathrm{COOH}$ ); $\operatorname{tr}_{\mathrm{LCMS}} 3.47 \mathrm{~min} ; \mathrm{MS}[\mathrm{M}-\mathrm{H}]^{-} \mathrm{m} / \mathrm{z} 224$. The previous carboxylic acid (115 $\mathrm{mg}, 0.5 \mathrm{mmol})$ was dissolved in DMF (5mL) and DIEA (260 $\mu \mathrm{L}, 1.5 \mathrm{mmol})$, EDCI (108 mg, 0.55 mmol) and HOBt (86 mg, $0.55 \mathrm{mmol}$ ) were added. The reaction mixture was stirred at room temperature for $5 \mathrm{~min}$ and O-tritylhydroxylamine $(103 \mathrm{mg}, 0.38 \mathrm{mmol})$ was added. The reaction mixture was stirred at room temperature overnight and evaporated. The crude product was dissolved in ethyl acetate, washed 3 times with aq. $1 \mathrm{~N} \mathrm{NaOH}$ solution and once with aq. $\mathrm{NaCl}$, dried over $\mathrm{MgSO} 4$, filtered and evaporated. The residue was purified by TLC (DCM/MeOH 97/3) and precipitated in petroleum ether to give $\mathrm{N}$-(4-Fluoro-benzyl)-2-methyl-N'-trityloxy-malonamide as a white powder (19\%). Purity 99\%; $\operatorname{tr}_{\mathrm{LCMS}} 7.05 \mathrm{~min} ; \mathrm{MS}[\mathrm{M}-\mathrm{H}]^{-} \mathrm{m} / \mathrm{z}$ 481. The protected hydroxamic acid (34 mg; 0.07 mmol) was dissolved in TFA 2\%/DCM $(0.03 \mathrm{M})$, and triisopropylsilane was added drop by drop until the yellow color disappeared. The reaction mixture was stirred $5 \mathrm{~min}$ at room temperature, solvents were removed under reduced pressure, and the residue was washed with petroleum ether to give (8) as a white powder (89\%). Purity 97\%; ${ }^{1} \mathrm{H}$ NMR $\left(\mathrm{CD}_{3} \mathrm{OD}\right) \delta 1.41(\mathrm{~d} ; \mathrm{J}=7.2 \mathrm{~Hz} ; 3 \mathrm{H}) ; 3.17(\mathrm{q} ; \mathrm{J}=7.2 \mathrm{~Hz}$; $1 \mathrm{H}) ; 4.37(\mathrm{~s} ; 2 \mathrm{H}) ; 7.02-7.07(\mathrm{~m} ; 2 \mathrm{H}) ; 7.29-7.34(\mathrm{~m} ; 2 \mathrm{H}) ; \mathrm{NMR}{ }^{13} \mathrm{C} \mathrm{CD}_{3} \mathrm{OD} \delta \mathrm{ppm}: 14.2 ; 42.0 ; 45.0$; $114.7\left(\mathrm{~d}, \mathrm{~J}_{\mathrm{CF}}=22.0 \mathrm{~Hz}\right) ; 128.9\left(\mathrm{~d}, \mathrm{~J}_{\mathrm{CF}}=8.2 \mathrm{~Hz}\right) ; 134.4 ; 162.1\left(\mathrm{~d}, \mathrm{~J}_{\mathrm{CF}}=244 \mathrm{~Hz}\right) ; 169.1 ; 171.1 . \operatorname{tr}_{\mathrm{LCMS}}$ $2.98 \mathrm{~min} ; \mathrm{MS}[\mathrm{M}+\mathrm{H}]^{+} \mathrm{m} / \mathrm{z} 241$.

N-(4-Fluoro-benzyl)-N'-hydroxy-2,2-dimethyl-malonamide (9) : 2,2-Dimethylmalonic acid diethyl ester $(950 \mu \mathrm{L}, 5 \mathrm{mmol})$ was dissolved in $\mathrm{EtOH}(20 \mathrm{~mL})$ and $\mathrm{KOH}(280 \mathrm{mg}, 5 \mathrm{mmol})$ was added. The solution was stirred at room temperature for $4 \mathrm{~h}$ and evaporated. The residue was dissolved in a $5 \%$ $\mathrm{NaHCO}_{3}$ solution and washed with DCM. The aqueous layer was acidified $(\mathrm{pH}=1)$ and extracted 3 times with DCM. The combined organic layers were dried over $\mathrm{MgSO}_{4}$, filtered and evaporated to 
give 2,2-dimethylmalonic acid diethyl ester as a colorless oil $(79 \%) .{ }^{1} \mathrm{H} \mathrm{NMR}\left(\mathrm{CDCl}_{3}\right) \delta 1.27(\mathrm{t} ; \mathrm{J}=$ $7.2 \mathrm{~Hz} ; 3 \mathrm{H}) ; 1.46$ (s; 6H); 4.20 (q; J = 7.2 Hz; 2H). 2,2-Dimethylmalonic acid diethyl ester (575 mg, $3.5 \mathrm{mmol})$ was dissolved in DMF (10 mL) and DIEA (2.12 mL, $12.2 \mathrm{mmol})$. EDCI (805 mg, 4.2 mmol) and HOBt (643 $\mathrm{mg}, 4.2 \mathrm{mmol})$ were added and the reaction mixture was stirred at room temperature for $5 \mathrm{~min}$. 4-fluorobenzylamine $(402 \mu \mathrm{L}, 3.5 \mathrm{mmol})$ was added, the solution was stirred overnight and evaporated. The residue was dissolved in DCM and washed 3 times with aq. $\mathrm{NaHCO}_{3}$ $5 \%$ and 3 times with $1 \mathrm{~N} \mathrm{HCl}$ solution, and once with brine, dried over $\mathrm{MgSO}_{4}$, filtered and evaporated to give N-(4-Fluoro-benzyl)-2,2-dimethyl-malonamic acid ethyl ester as a white powder (85\%). Purity 95\%; 1H NMR $\left(\mathrm{CD}_{2} \mathrm{Cl}_{2}\right) \delta: 1.26(\mathrm{t} ; \mathrm{J}=7.2 \mathrm{~Hz} ; 3 \mathrm{H}) ; 1.47(\mathrm{~s} ; 6 \mathrm{H}) ; 4.18(\mathrm{q} ; \mathrm{J}=7.2 \mathrm{~Hz} ; 2 \mathrm{H}) ; 4.42(\mathrm{~d} ; \mathrm{J}$ $=5.7 \mathrm{~Hz} ; 2 \mathrm{H}) ; 6.67(\mathrm{br} \mathrm{s} ; \mathrm{NH}) ; 7.01-7.09(\mathrm{~m} ; 2 \mathrm{H}) ; 7.24-7.30(\mathrm{~m} ; 2 \mathrm{H}) ; \operatorname{tr}_{\mathrm{LCMS}} 5.01 \mathrm{~min} ; \mathrm{MS}[\mathrm{M}+\mathrm{H}]^{+}$ m/z 268. Ester (535 mg, $2 \mathrm{mmol}$ ) was added to a solution of $\mathrm{KOH}(337 \mathrm{mg}, 6 \mathrm{mmol})$ in EtOH $(7 \mathrm{~mL})$. The solution was stirred at room temperature overnight and evaporated. The residue was dissolved in $\mathrm{H}_{2} \mathrm{O}$ and washed with DCM. The aqueous layer was acidified and extracted 3 times with DCM. The combined organic layers were dried over $\mathrm{MgSO}_{4}$, filtered and evaporated to give $\mathrm{N}$-(4-Fluoro-benzyl)2,2-dimethyl-malonamic acid as a white powder (80\%). Purity 99\%; ${ }^{1} \mathrm{H}$ NMR (DMSO-d6) $\delta 1.31$ (s; $6 \mathrm{H}) ; 4.24(\mathrm{~d} ; J=6 \mathrm{~Hz} ; 2 \mathrm{H}) ; 7.09-7.15(\mathrm{~m} ; 2 \mathrm{H}) ; 7.27-7.28(\mathrm{~m} ; 2 \mathrm{H}) ; 8.25(\mathrm{t} ; J=6 \mathrm{~Hz} ; \mathrm{NH}) ; 12.53$ (br s; $\mathrm{COOH}) ; \operatorname{tr}_{\text {LCMS }} 3.78 \mathrm{~min} ; \mathrm{MS}[\mathrm{M}-\mathrm{H}]^{-} \mathrm{m} / \mathrm{z} 238$. Acid (48 mg, $0.2 \mathrm{mmol}$ ) was dissolved in DCM (1.5 $\mathrm{mL})$ with catalytic DMF $(10 \mu \mathrm{L})$. The mixture was cooled at $0{ }^{\circ} \mathrm{C}$ (ice bath), and oxalyl chloride (20.6 $\mu \mathrm{L}, 0.24 \mathrm{mmol}$ ) was added dropwise. The reaction mixture was stirred $45 \mathrm{~min}$ at $0{ }^{\circ} \mathrm{C}$ and then evaporated under reduced pressure. The residue was dissolved in DCM $(1.5 \mathrm{~mL})$ and cooled at $0{ }^{\circ} \mathrm{C}$. DIEA (123 $\mu \mathrm{L}, 0.48 \mathrm{mmol})$ was added and then O-trityl-hydroxylamine $(41 \mathrm{mg}, 0.15 \mathrm{mmol})$ was added. The reaction mixture was stirred $2 \mathrm{~h}$ at room temperature. The residue was dissolved in ethyl acetate and washed with $\mathrm{NaHCO}_{3} 5 \%$ and brine. The organic phase was washed dried over $\mathrm{MgSO}_{4}$, and evaporated under reduced pressure. The crude product was purified by TLC (DCM/MeOH 95/5) to give N-(4-Fluoro-benzyl)-2,2-dimethyl-N'-trityloxy-malonamide as a white powder (63\%). Purity 99\%; $\operatorname{tr}_{\mathrm{LCMS}} 7.60 \mathrm{~min} ; \mathrm{MS}[\mathrm{M}-\mathrm{H}]^{-} \mathrm{m} / \mathrm{z}$ 495. The protected hydroxamic acid (31 mg; $\left.0.062 \mathrm{mmol}\right)$ was dissolved in TFA 2\%/DCM (0.03 M), and triisopropylsilane was added drop by drop until the yellow color disappeared. The reaction mixture was stirred $5 \mathrm{~min}$ at room temperature, solvents were removed 
under reduced pressure, and the residue was washed with petroleum ether and purified by TLC (DCM/MeOH/TEA 6/1.5/2.5) to give (9) as a beige powder (75\%). Purity 99\%; ${ }^{1} \mathrm{H}$ NMR $\left(\mathrm{CD}_{3} \mathrm{OD}\right)$ cis/trans isomer mixture $(55 / 45) \delta: 1.31(\mathrm{~s} ; 1.35 \mathrm{H}) ; 1.41(\mathrm{~s} ; 1.35 \mathrm{H}) ; 1.44(\mathrm{~s} ; 3.3 \mathrm{H}) ; 4.12(\mathrm{~s} ; 1.1 \mathrm{H})$; $4.37(\mathrm{~s} ; 0.9 \mathrm{H}) ; 7.04(\mathrm{t} ; J=8.7 \mathrm{~Hz} ; 0.9 \mathrm{H}) ; 7.20(\mathrm{t} ; J=8.7 \mathrm{~Hz} ; 1.1 \mathrm{H}) ; 7.28-7.31(\mathrm{~m} ; 0.9 \mathrm{H}) ; 7.44-7.48$ (m; $1.1 \mathrm{H}) ; \operatorname{tr}_{\text {LCMS }} 3.18 \mathrm{~min} ; \mathrm{MS}[\mathrm{M}+\mathrm{H}]^{+} \mathrm{m} / \mathrm{z} 255$.

Cyclopropane-1,1-dicarboxylic acid 4-fluoro-benzylamide hydroxyamide (10) : Cyclopropane1,1-dicarboxylic acid diethyl ester $(887 \mu \mathrm{L}, 5 \mathrm{mmol})$ was dissolved in EtOH $(20 \mathrm{~mL})$ and $\mathrm{KOH}(280$ $\mathrm{mg}, 5 \mathrm{mmol}$ ) was added. The solution was stirred at room temperature for $4 \mathrm{~h}$ and evaporated. The residue was dissolved in a $5 \% \mathrm{NaHCO}_{3}$ solution and washed with DCM. The aqueous layer was acidified $(\mathrm{pH}=1)$ and extracted 3 times with DCM. The combined organic layers were dried over $\mathrm{MgSO}_{4}$, filtered and evaporated to give cyclopropane-1,1-dicarboxylic acid ethyl ester $(79 \%) .{ }^{1} \mathrm{H}$ $\operatorname{NMR}\left(\mathrm{CDCl}_{3}\right) \delta 1.28(\mathrm{t} ; J=7.2 \mathrm{~Hz} ; 3 \mathrm{H}) ; 1.73-1.78(\mathrm{~m} ; 2 \mathrm{H}) ; 1.82-1.86(\mathrm{~m} ; 2 \mathrm{H}) ; 4.25(\mathrm{q} ; J=7.2 \mathrm{~Hz} ;$ $2 \mathrm{H})$. The previous carboxylic acid $(568 \mathrm{mg}, 3.5 \mathrm{mmol})$ was dissolved in DMF (10 mL) and DIEA (2.12 mL, $12.2 \mathrm{mmol})$. EDCI ( $805 \mathrm{mg}, 4.2 \mathrm{mmol})$ and HOBt (643 mg, $4.2 \mathrm{mmol}$ ) were added and the reaction mixture was stirred at room temperature for $5 \mathrm{~min}$. 4-fluorobenzylamine ( $402 \mu \mathrm{L}, 3.5 \mathrm{mmol})$ was added, the solution was stirred overnight and evaporated. The residue was dissolved in DCM and washed 3 times with aq. $\mathrm{NaHCO}_{3} 5 \%$ and 3 times with $1 \mathrm{~N} \mathrm{HCl}$ solution, and once with brine, dried over $\mathrm{MgSO}_{4}$, filtered and evaporated to give 1-(4-Fluoro-benzylcarbamoyl)-cyclopropanecarboxylic acid ethyl ester (59\%). Purity 95\%; ${ }^{1} \mathrm{H}$ NMR $\left(\mathrm{CD}_{2} \mathrm{Cl}_{2}\right) \delta 1.24(\mathrm{t} ; J=7.2 \mathrm{~Hz} ; 3 \mathrm{H}) ; 1.57-1.69(\mathrm{~m} ; 4 \mathrm{H})$; $4.13(\mathrm{q} ; J=7.2 \mathrm{~Hz} ; 2 \mathrm{H}) ; 4.47(\mathrm{~d} ; J=5.7 \mathrm{~Hz} ; 2 \mathrm{H}) ; 7.02-7.10(\mathrm{~m} ; 2 \mathrm{H}) ; 7.29-7.35(\mathrm{~m} ; 2 \mathrm{H}) ; 9.10$ (br s; $\mathrm{NH}) . \operatorname{tr}_{\mathrm{LCMS}} 5.52 \mathrm{~min} ; \mathrm{MS}[\mathrm{M}+\mathrm{H}]^{+} \mathrm{m} / \mathrm{z} 266$. Ester $(530 \mathrm{mg}, 2 \mathrm{mmol})$ was added to a solution of $\mathrm{KOH}$ (337 mg, $6 \mathrm{mmol})$ in EtOH $(7 \mathrm{~mL})$. The solution was stirred at room temperature overnight and evaporated. The residue was dissolved in $\mathrm{H}_{2} \mathrm{O}$ and washed with DCM. The aqueous layer was acidified and extracted 3 times with DCM. The combined organic layers were dried over $\mathrm{MgSO}_{4}$, filtered and evaporated to give 1-(4-Fluoro-benzylcarbamoyl)-cyclopropanecarboxylic acid as a white powder (87\%). Purity 98\%; ${ }^{1} \mathrm{H}$ NMR (DMSO-d6) $\delta 1.34-1.42(\mathrm{~m} ; 4 \mathrm{H}) ; 4.33(\mathrm{~d} ; J=5.7 \mathrm{~Hz} ; 2 \mathrm{H}) ; 7.10-$ $7.18(\mathrm{~m} ; 2 \mathrm{H}) ; 7.28-7.34(\mathrm{~m} ; 2 \mathrm{H}) ; 9.06(\mathrm{t} ; J=5.7 \mathrm{~Hz} ; \mathrm{NH}) ; 13.07$ (br s; COOH); tr $\operatorname{tr}_{\text {LCMS }} 3.96 \mathrm{~min} ; \mathrm{MS}$ 
$[\mathrm{M}-\mathrm{H}]^{-} \mathrm{m} / \mathrm{z}$ 236. Acid $(47 \mathrm{mg}, 0.2 \mathrm{mmol})$ was dissolved in DCM $(1.5 \mathrm{~mL})$ with catalytic DMF (10 $\mu \mathrm{L})$. The mixture was cooled at $0{ }^{\circ} \mathrm{C}$ (ice bath), and oxalyl chloride $(20.6 \mu \mathrm{L}, 0.24 \mathrm{mmol})$ was added dropwise. The reaction mixture was stirred $45 \mathrm{~min}$ at $0{ }^{\circ} \mathrm{C}$ and then evaporated under reduced pressure. The residue was dissolved in DCM $(1.5 \mathrm{~mL})$ and cooled at $0{ }^{\circ} \mathrm{C}$. DIEA $(123 \mu \mathrm{L}, 0.48 \mathrm{mmol})$ was added and then O-trityl-hydroxylamine $(41 \mathrm{mg}, 0.15 \mathrm{mmol}$ ) was added. The reaction mixture was stirred $2 \mathrm{~h}$ at room temperature. The residue was dissolved in ethyl acetate and washed with $\mathrm{NaHCO}_{3}$ $5 \%$ and brine. The organic phase was washed dried over $\mathrm{MgSO}_{4}$, and evaporated under reduced pressure. The crude product was purified by TLC (DCM/MeOH 95/5) to give cyclopropane-1,1dicarboxylic acid 4-fluoro-benzylamide trityloxy-amide as a yellow powder (49\%). Purity 99\%; $\operatorname{tr}_{\text {LCMS }} 7.52 \mathrm{~min} ; \mathrm{MS}[\mathrm{M}-\mathrm{H}]^{-} \mathrm{m} / \mathrm{z}$ 493. The protected hydroxamic acid (32 $\mathrm{mg} ; 0.065 \mathrm{mmol}$ ) was dissolved in TFA 2\%/DCM $(0.03 \mathrm{M})$, and triisopropylsilane was added dropwise until the yellow color disappeared. The reaction mixture was stirred $5 \mathrm{~min}$ at room temperature, solvents were removed under reduced pressure, and the residue was washed with petroleum ether and purified by TLC (DCM/MeOH/TEA 6/1.5/2.5) to give (10) as a beige powder (75\%). Purity 99\%; ${ }^{1} \mathrm{H}$ NMR $\left(\mathrm{CD}_{3} \mathrm{OD}\right)$ cis/trans isomer mixture $(65 / 35) \delta$ 1.29-133 (m; 2H); 1.37-1.41 (m; 2H); $4.12(\mathrm{~s} ; 0.7 \mathrm{H}) ; 4.39(\mathrm{~s} ; 1.3$ $\mathrm{H}) ; 7.05(\mathrm{t} ; \mathrm{J}=8.7 \mathrm{~Hz} ; 1.3 \mathrm{H}) ; 7.20(\mathrm{t} ; \mathrm{J}=8.7 \mathrm{~Hz} ; 0.7 \mathrm{H}) ; 7.29-7.35(\mathrm{~m} ; 1.3 \mathrm{H}) ; 7.46-7.51(\mathrm{~m} ; 0.7 \mathrm{H})$; $\mathrm{NMR}{ }^{13} \mathrm{C} \mathrm{CD}_{3} \mathrm{OD} \delta$ ppm : 14.1; 27.1; 42.2 (A form); 42.3 (B form); 114.7 (d, $\mathrm{J}_{\mathrm{CF}}=22.3 \mathrm{~Hz}$ ) (A form); $115.6\left(\mathrm{~d}, \mathrm{~J}_{\mathrm{CF}}=22.3 \mathrm{~Hz}\right)(\mathrm{B}$ form $) ; 128.9\left(\mathrm{~d}, \mathrm{~J}_{\mathrm{CF}}=8.0 \mathrm{~Hz}\right)(\mathrm{A}$ form $) ; 130.9\left(\mathrm{~d}, \mathrm{~J}_{\mathrm{CF}}=8.5 \mathrm{~Hz}\right)(\mathrm{B}$ form$)$; 134.6 (A form); $137.6\left(\mathrm{~B}\right.$ form); $162.0\left(\mathrm{~d}, \mathrm{~J}_{\mathrm{CF}}=243 \mathrm{~Hz}\right)(\mathrm{A}$ form $) ; 163.2\left(\mathrm{~d}, \mathrm{~J}_{\mathrm{CF}}=247 \mathrm{~Hz}\right)(\mathrm{B}$ form$)$; 169.0; 170.7. $\operatorname{tr}_{\mathrm{LCMS}} 3.18 \mathrm{~min} ; \mathrm{MS}[\mathrm{M}+\mathrm{H}]^{+} \mathrm{m} / \mathrm{z} 253$.

2-[2-(4-Fluoro-phenyl)-acetylamino]-N-hydroxy-3-phenyl-propionamide (11) : 2-Chlorotrityl NFmoc-Hydroxylamine, polymer-bound, 100-200 mesh (1.504 g, $0.68 \mathrm{mmol})$ was treated with a piperidine/DMF 20/80 cocktail for 30 minutes to remove the Fmoc- protecting group. The resin was washed with DMF and DCM. $N$-Fmoc-phenylalanine (1.050 g, $2.71 \mathrm{mmol}, 4$ eq.) was activated with HATU (1.030 g, $2.71 \mathrm{mmol}, 4$ eq.) in $15 \mathrm{~mL}$ of DMF and DIEA (895 $\mu \mathrm{L}, 5.42 \mathrm{mmol}, 8$ eq.). The mixture was then added to the resin. The resin was shaken overnight at room temperature then washed with DMF and DCM. The coupling was performed twice. To remove the Fmoc protecting group, the 
resin was treated with a piperidine/DMF 20/80 cocktail for 30 minutes. Half of the resin was used for the next step. The resin was washed with DMF. 4-fluorophenylacetic acid (210 mg, $1.35 \mathrm{mmol}, 4$ eq.) was activated with HOBt (210 mg, $1.35 \mathrm{mmol}, 4$ eq.) and TBTU (435 mg, $1.35 \mathrm{mmol}, 4$ eq.) in $7 \mathrm{~mL}$ of DMF and DIEA ( $450 \mu \mathrm{L}, 2.71 \mathrm{mmol}, 8$ eq.). The mixture was then added to the resin. The resin was shaken $3 \mathrm{~h}$ at room temperature then washed with DMF and DCM. The coupling was performed twice and the resin was washed with DCM. Cleavage from the resin was accomplished by treatment with a mixture of TFA $(100 \mu \mathrm{L})$, TIS $(50 \mu \mathrm{L})$ in DCM $(5 \mathrm{~mL})$ for 2 minutes. The resin was filtered and the cleavage was performed 5 times. The filtrate was neutralized with a piperidine/methanol/water 10/45/45 mixture to avoid the conversion of hydroxamic acid into carboxylic acid. The organic solvents were evaporated under reduced pressure and the aqueous phase was extracted 4 times with ethyl acetate. The combined organic layers were washed with water and brine then dried over $\mathrm{MgSO}_{4}$ and evaporated. The residue was washed with petroleum ether to obtain (11) as a beige powder (81 \%). Purity 98\%; ${ }^{1} \mathrm{H}$ NMR (DMSO-d6) $\delta: 2.73-2.80(\mathrm{~m} ; 1 \mathrm{H}) ; 2.90-2.95(\mathrm{~m} ; 1 \mathrm{H}) ; 3.35(\mathrm{~s} ; 2 \mathrm{H}) ; 4.36-$ $4.40(\mathrm{~m} ; 1 \mathrm{H}) ; 7.03-7.21(\mathrm{~m} ; 9 \mathrm{H}) ; 8.45(\mathrm{~d} ; \mathrm{J}=5.7 \mathrm{~Hz} ; \mathrm{CONH}) ; 8.90(\mathrm{~s} ; \mathrm{OH}) ; 10.74(\mathrm{~s} ; \mathrm{CONHO}) ; \mathrm{NMR}$ ${ }^{13} \mathrm{C}$ DMSO-d6 $\delta$ ppm : 38.5; 41.5; 52.2; $115.2\left(\mathrm{~d}, \mathrm{~J}_{\mathrm{CF}}=21.1 \mathrm{~Hz}\right) ; 126.7 ; 128.5 ; 129.6 ; 131.2\left(\mathrm{~d}, \mathrm{~J}_{\mathrm{CF}}=\right.$ $7.6 \mathrm{~Hz}) ; 132.9 ; 138.1 ; 161.4\left(\mathrm{~d}, \mathrm{~J}_{\mathrm{CF}}=238.2 \mathrm{~Hz}\right) ; 168.2 ; 170.1 ; \mathrm{t}_{\mathrm{R}} \mathrm{LCMS}_{4} 4.29 \mathrm{~min} ; \mathrm{MS}[\mathrm{M}-\mathrm{H}]^{-} \mathrm{m} / \mathrm{z} 315$.

N-Hydroxy-benzamide (12): Benzoic acid (12a) (354 mg; 2.9 mmol) was dissolved in DCM (0.4M) with catalytic DMF. To this solution cooled to $0{ }^{\circ} \mathrm{C}$ (ice bath), was added dropwise oxalyl chloride (299 $\mu \mathrm{L} ; 3.48 \mathrm{mmol}$ ). The mixture was stirred at room temperature for $1 \mathrm{~h}$ and evaporated under reduced pressure (temp. max. $25^{\circ} \mathrm{C}$ ). The residue was dissolved in DCM (0.4M). To this solution cooled to $0{ }^{\circ} \mathrm{C}$ (ice bath) was added dropwise DIEA $(1,4 \mathrm{ml} ; 1.2 \mathrm{~g} ; 7.8 \mathrm{mmol}$.). Then, Otritylhydroxylamine $(878 \mathrm{mg} ; 3.19 \mathrm{mmol})$ was added and the mixture was stirred at room temperature for 4h. Control of reaction was performed by TLC (DCM/MeOH 95/5, UV and $\mathrm{H}_{2} \mathrm{SO}_{4}$ visualization) The mixture was washed once with aq. $\mathrm{NaHCO}_{3} 5 \%$, three times with water and the combined organic layers were dried over $\mathrm{MgSO}_{4}$ and evaporated. O-trityle hydroxamate intermediate was dissolved in TFA 2\%/DCM $(0.03 \mathrm{M})$ and triisopropylsilane is added dropwise until the yellow color disappeared. Solvents were removed under reduced pressure and the residue was washed with petroleum ether to 
give compound (12) (47\%). White powder; purity $100 \% ;{ }^{1} \mathrm{H}$ NMR $300 \mathrm{MHz}$ (DMSO- $d 6$ ) $\delta \mathrm{ppm}: 7.45$ $(\mathrm{m} ; 3 \mathrm{H}) ; 7.74(\mathrm{~d}, J=9 \mathrm{~Hz}, 2 \mathrm{H}) ; 9.00(\mathrm{~s}, 1 \mathrm{H}) ; 11.19(\mathrm{~s}, 1 \mathrm{H}) ;{ }^{13} \mathrm{C} \mathrm{NMR}(\mathrm{MeOD}) \delta \mathrm{ppm}: 166.8,132.2$, $131.4,128.3,126.7 \mathrm{mp}: 129,6-131^{\circ} \mathrm{C}$; $\operatorname{tr}_{\mathrm{LCMS}} 2.9 \mathrm{~min}, \mathrm{MS}[\mathrm{M}+\mathrm{H}]^{+} \mathrm{m} / \mathrm{z} 138$.

N-Hydroxy-2-phenyl-acetamide (13): Phenylacetic acid (13a) (500 mg, $3.67 \mathrm{mmol})$ was dissolved in DCM (42 ml) with DIEA (2.43 ml, $1.9 \mathrm{~g} ; 14.69 \mathrm{mmol})$. EDCI (774 mg; $4.04 \mathrm{mmol})$ and HOBt (618 $\mathrm{mg} ; 4.04 \mathrm{mmol}$ ) were added. The mixture was stirred at room temperture for $5 \mathrm{~min}$ and the $\mathrm{O}$ tritylhydroxylamine $(1.01 \mathrm{~g} ; 3.33 \mathrm{mmol})$ was added. The mixture was stirred at room temperature for 5h. The reaction mixture was evaporated under reduced pressure, the residue was dissolved in DCM and washed three times with aq. $\mathrm{NaHCO}_{3}$ solution (5\%), once with water and the organic layer was dried over $\mathrm{MgSO}_{4}$ and evaporated. O-trityle hydroxamate intermediate was dissolved in TFA 5\% / DCM $(0.03 \mathrm{M})$ and triisopropylsilane was added dropwise until the yellow color disappeared. Solvents were removed under reduced pressure and the residue was washed with petroleum ether to give compound (13). Yield 30\%. White powder, purity 100\%, ${ }^{1} \mathrm{H}$ NMR $300 \mathrm{MHz}$ (DMSO- $d 6$ ) $\delta$ ppm: 3.27 (s, 2H), 726 (m, 5H), 8.75 (br s, 1H), 10.64 (s, 1H); ${ }^{13} \mathrm{C}$ NMR (MeOD) $\delta$ ppm: 169.4, 135.1, 128.6, 128.1, 126.6, 39.2; $\operatorname{tr}_{\text {LCMS }} 2.4 \mathrm{~min}, \mathrm{MS}[\mathrm{M}+\mathrm{H}]^{+} \mathrm{m} / \mathrm{z} 152$.

N-Hydroxy-3-phenyl-propionamide (14) : 3-Phenyl-propionic acid (14a) (500mg, 3.33 mmol) was dissolved in DCM (40 mL). EDCI (702 mg; $3.66 \mathrm{mmol})$; HOBt (561 mg; $3.66 \mathrm{mmol})$ and DIEA (2206 $\mu \mathrm{L}, 13.3 \mathrm{mmol}$ ) were added. The mixture was stirred at room temperature for $5 \mathrm{~min}$ and $\mathrm{O}$ Tritylhydroxylamine (917 mg; $3.33 \mathrm{mmol}$ ) was added. The mixture was stirred at room temperature for $5 \mathrm{~h}$. The solvent was evaporated under reduced pressure, the residue was dissolved in DCM and washed three times with aq $\mathrm{NaHCO}_{3}$ solution (5\%), once with water and the organic layer was dried over $\mathrm{MgSO}_{4}$ and evaporated. O-Trityle hydroxamate intermediate was dissolved in TFA 5\%/DCM $(0.03 \mathrm{M})$ and triisopropylsilane is added dropwise until the yellow color disappeared. Solvents were removed under reduced pressure and the residue was washed with petroleum ether to give compound (14) (10\%). White powder, purity 98\%, ${ }^{1} \mathrm{H}$ NMR 300MHz (DMSO-d6) $\delta$ ppm: 2.24 (t, $J=7.2 \mathrm{~Hz}, 2 \mathrm{H}$ ), 
$2.79(\mathrm{t}, J=7.0 \mathrm{~Hz}, 2 \mathrm{H}) 7.29-7.16(\mathrm{~m}, 5 \mathrm{H}), 8.68(\mathrm{~s}, 1 \mathrm{H}), 10.35(\mathrm{~s}, 1 \mathrm{H}) ;{ }^{13} \mathrm{C}$ NMR $(\mathrm{MeOD}) \delta \mathrm{ppm}:$ $171.9,142.2,129.5,129.4,127.2,35.7,32.6 ; \operatorname{tr}_{\mathrm{LCMS}} 3.1 \mathrm{~min}, \mathrm{MS}[\mathrm{M}+\mathrm{H}]^{+} \mathrm{m} / \mathrm{z} 166$

N-Hydroxy-4-phenyl-butyramide (15) : 4-Phenyl-butyric acid (15a) (1g, $6.09 \mathrm{mmol})$ is dissolved in DCM $(15 \mathrm{~mL})$ and DMF $(30 \mu \mathrm{L})$ was added. The reaction mixture is cooled to $0{ }^{\circ} \mathrm{C}$ (ice bath) and oxalyl chloride $(627 \mu \mathrm{L}, 7.3 \mathrm{mmol})$ is added dropwise. Reaction mixture was stirred at room temperature for $1 \mathrm{~h}$.The solvent was evaporated under reduced pressure, the residue was dissolved in DCM $(10 \mathrm{~mL})$ and O-Tritylhydroxylamine $(1425 \mathrm{mg} ; 5.17 \mathrm{mmol})$ in solution in DCM $(5 \mathrm{~mL})$ with DIEA ( $3 \mathrm{~mL}, 18.27 \mathrm{mmol}$ ) was added dropwise. The mixture was stirred at room temperature for $3 \mathrm{~h}$ and washed three times with aq $\mathrm{NaHCO}_{3}$ solution (5\%), once with water and the organic layer was dried over $\mathrm{MgSO}_{4}$ and evaporated. The residue was precipitated in diethyl ether and filtrated. O-trityle hydroxamate intermediate was dissolved in TFA 5\%/DCM (0.03 M) and triisopropylsilane was added dropwise until the yellow color disappeared. Solvents were removed under reduced pressure and the residue was washed with diethyl ether/pentane 50/50 and 25/75 mixture to give compound (15) (68\%). White powder, purity 98\%, ${ }^{1} \mathrm{H}$ NMR 300MHz (DMSO- $\left.d 6\right) \delta \mathrm{ppm}: 1.78(\mathrm{~m}, 2 \mathrm{H}), 1.96(\mathrm{t}, J=9.0 \mathrm{~Hz}$, $2 \mathrm{H}), 2.54(\mathrm{t}, J=9.0 \mathrm{~Hz}, 2 \mathrm{H}), 7.33-7.10(\mathrm{~m}, 5 \mathrm{H}), 8.66(\mathrm{~s}, 1 \mathrm{H}), 10.35(\mathrm{~s}, 1 \mathrm{H}) ;{ }^{13} \mathrm{C} \mathrm{NMR}(\mathrm{MeOD}) \delta \mathrm{ppm}$ : $172.7,142.8,129.4,129.3,126.9,36.2,33.2,28.6 ; \operatorname{tr}_{\mathrm{LCMS}} 4.5 \mathrm{~min}, \mathrm{MS}[\mathrm{M}+\mathrm{H}]^{+} \mathrm{m} / \mathrm{z} 180$.

(E)-N-Hydroxy-3-phenyl-acrylamide (16): (E)-3-Phenyl-acrylic acid (16a) (300 mg, 2.02 mmol) is dissolved in DMF (20 mL). EDCI (465 mg; $2.42 \mathrm{mmol})$; HOBt (465 mg; $3.03 \mathrm{mmol})$ and NMM $(890 \mu \mathrm{L}, 13.3 \mathrm{mmol})$ were added. The mixture was stirred at room temperature for $5 \mathrm{~min}$ and $\mathrm{O}$ Tritylhydroxylamine (669 mg; $2.42 \mathrm{mmol}$ ) was added. The mixture was stirred at room temperature overnight. The solvent was evaporated under reduced pressure, the residue was dissolved in DCM and washed three times with aq. $\mathrm{NaHCO}_{3}(5 \%)$, once with water and the organic layer was dried over $\mathrm{MgSO}_{4}$ and evaporated. O-trityle hydroxamate intermediate was dissolved in TFA 5\%/DCM (19 mL) and triisopropylsilane was added dropwise until the yellow color disappeared. Solvents were removed under reduced pressure and the residue was washed with petroleum ether to give compound (16) (87\%). White powder, purity 98\%, ${ }^{1} \mathrm{H}$ NMR 300MHz (DMSO- $\left.d 6\right) \delta$ ppm: 6.45 (d, $J=15.6 \mathrm{~Hz}, 1 \mathrm{H}$ ), 
7.38-7.56 (m, 5H + 1H), $9.03(\mathrm{~s}, 1 \mathrm{H}), 10.09(\mathrm{~s}, 1 \mathrm{H}) ;{ }^{13} \mathrm{C}$ NMR (DMSO-d6) $\delta \mathrm{ppm:} \mathrm{164.9,} \mathrm{140.3,}$ 134.7, 129.5, 128.6, 127.4, 116.9; $\operatorname{tr}_{\text {LCMS }} 3.30 \mathrm{~min}, \mathrm{MS}[\mathrm{M}+\mathrm{H}]^{+} \mathrm{m} / \mathrm{z} 164$.

N-Hydroxy-2-phenoxy-acetamide (17): Phenoxyacetic acid (17a) (300 mg; 1,97 mmol) was dissolved in DMF (20 ml). O-Tritylhydroxylamine (649.8 mg; $2.36 \mathrm{mmol}$ ); EDCI (452.43 mg; 2.36 mmol); HOBt (451.76 mg; $2.95 \mathrm{mmol})$ and NMM (866 $\mu \mathrm{L} ; 797.0 \mathrm{mg} ; 7.88 \mathrm{mmol})$ were added. The mixture was stirred at room temperature for $16 \mathrm{~h}$. The reaction mixture was evaporated under reduced pressure, the residue was dissolved in DCM and washed three times with aq $\mathrm{NaHCO}_{3}$ solution (5\%), once with water and the organic layer was dried over $\mathrm{MgSO}_{4}$ and evaporated. O-Trityle hydroxamate intermediate was dissolved in TFA 5\%/DCM $(0.03 \mathrm{M})$ and triisopropylsilane was added dropwise until the yellow color disappeared. Solvents were removed under reduced pressure and the residue was washed with petroleum ether to give compound (17) (7\%). White powder, purity $98 \%,{ }^{1} \mathrm{H}$ NMR 300MHz (DMSO-d6) $\delta$ ppm: 4,62 (s, 2H); 6,94 (d, $J=8,1 \mathrm{~Hz}, 2 \mathrm{H}) ; 7,05$ (t, $J=7,2 \mathrm{~Hz}, 1 \mathrm{H}) ; 7,34$ (t, $J=7,8 \mathrm{~Hz}, 2 \mathrm{H}) ; 9,24$ (br s, 1H); $\operatorname{tr}_{\mathrm{LCMS}} 2.85 \mathrm{~min}, \mathrm{MS}[\mathrm{M}+\mathrm{H}]^{+} \mathrm{m} / \mathrm{z} 168$.

N-Hydroxy-3-phenoxy-propionamide (18) : 3-Phenoxy-propionic acid (18a) (300 mg, $2.80 \mathrm{mmol}$ ) is dissolved in DMF (20 mL). EDCI (415 mg; $2.16 \mathrm{mmol})$; HOBt (415 mg; $2.70 \mathrm{mmol})$ and NMM $(793 \mu \mathrm{L}, 7.2 \mathrm{mmol})$ were added. The mixture was stirred at room temperature for $5 \mathrm{~min}$ and $\mathrm{O}-$ Tritylhydroxylamine (497 mg; $2.16 \mathrm{mmol}$ ) was added. The mixture was stirred at room temperature overnight. The solvent was evaporated under reduced pressure, the residue was dissolved in DCM and washed three times with aq. $\mathrm{NaHCO}_{3}(5 \%)$, once with water and the organic layer was dried over $\mathrm{MgSO}_{4}$ and evaporated. O-Trityle hydroxamate intermediate was dissolved in TFA 5\%/DCM (14 mL) and triisopropylsilane was added dropwise until the yellow color disappeared. Solvents are removed under reduced pressure and the residue was washed with diethyl ether/pentane and petroleum ether to give compound (18) (37\%). White powder, purity 98\%, ${ }^{1} \mathrm{H}$ NMR 300MHz (MeOD) $\delta$ ppm: $2.53(\mathrm{t}, J$ $=6.0 \mathrm{~Hz}, 1 \mathrm{H}), 4.22(\mathrm{t}, J=6.0 \mathrm{~Hz}, 1 \mathrm{H}), 6.91(\mathrm{~m}, 3 \mathrm{H}) 7.24(\mathrm{~m}, 2 \mathrm{H}) ; \operatorname{tr}_{\mathrm{LCMS}} 3.18 \mathrm{~min}, \mathrm{MS}[\mathrm{M}+\mathrm{H}]^{+} \mathrm{m} / \mathrm{z}$ 182. 
4-cyclopropylethynyl-N-hydroxy-benzamide (19) : Ethyl-4-iodobenzoate $(1.2 \mathrm{~mL}, 7.64 \mathrm{mmol})$, triethylamine (10.2 mL, $72.4 \mathrm{mmol}), \mathrm{CuI}(276 \mathrm{mg}, 1.45 \mathrm{mmol}), \mathrm{PdCl}_{2} \mathrm{P}\left(\mathrm{Ph}_{3}\right)_{2}$, ethynylcyclopropane (622 mg, $9.41 \mathrm{mmol})$ were dissolved in DMF $\left(28 \mathrm{~mL}\right.$ ). The mixture was stirred at $70{ }^{\circ} \mathrm{C}$ overnight. The solvent was evaporated under reduced pressure, the residue was dissolved in DCM and filtrated on celite. The DCM solution was washed with brine and the organic layer was dried over $\mathrm{MgSO}_{4}$ and evaporated. The residue was purified by flash chromatography (cyclohexane/ethyl acetate) to give Ethyl-4-cyclopropylethynyl-benzoate (yellow oil, 90\%). Purity 98\%, ${ }^{1} \mathrm{H}$ NMR 300MHz (DMSO) $\delta$ ppm: $0.85(\mathrm{~m}, 2 \mathrm{H}), 0.92(\mathrm{~m}, 2 \mathrm{H}), 1.31(\mathrm{t}, J=6.9 \mathrm{~Hz}, 3 \mathrm{H}) 1.58(\mathrm{~m}, 1 \mathrm{H}), 4.3(\mathrm{q}, J=7.2 \mathrm{~Hz}, 2 \mathrm{H}), 7.74$ $(\mathrm{d}, J=8.7 \mathrm{~Hz}, 2 \mathrm{H}), 7.89(\mathrm{~d}, J=8.7 \mathrm{~Hz}, 2 \mathrm{H}) ; \operatorname{tr}_{\mathrm{LCMS}} 7.5 \mathrm{~min}, \mathrm{MS}[\mathrm{M}+\mathrm{H}]^{+} \mathrm{m} / \mathrm{z} 215$. Ester $(1.3 \mathrm{~g}, 6.07$ mmol) and $\mathrm{NaOH}(486 \mathrm{mg}, 12.15 \mathrm{mmol})$ were dissolved in EtOH $(25 \mathrm{~mL})$ and $\mathrm{H}_{2} \mathrm{O}(500 \mu \mathrm{L})$. The mixture was stirred at room temperature overnight. The solvent was evaporated under reduced pressure. The residue was dissolved in DCM and washed with $\mathrm{HCl}(1 \mathrm{~N})$ solution. The organic layer was dried over $\mathrm{MgSO}_{4}$ and evaporated to give 4-cyclopropylethynylbenzoic acid (19a) (white solid, 98\%). Purity 98\%, ${ }^{1} \mathrm{H}$ NMR 300MHz (DMSO) $\delta$ ppm: $0.76(\mathrm{~m}, 2 \mathrm{H}), 0.91(\mathrm{~m}, 2 \mathrm{H}), 1.57(\mathrm{~m}, 1 \mathrm{H}), 7.44$ $(\mathrm{d}, J=8.4 \mathrm{~Hz}, 2 \mathrm{H}), 7.87(\mathrm{~d}, J=8.4 \mathrm{~Hz}, 2 \mathrm{H}) ; \operatorname{tr}_{\mathrm{LCMS}} 5.54 \mathrm{~min}, \mathrm{MS}(\mathrm{ESI}+): \mathrm{m} / \mathrm{z}=187(\mathrm{M}+\mathrm{H})^{+}, \mathrm{Mp}=$ 220-222 ${ }^{\circ}$ C. 4-Cyclopropylethynylbenzoic acid (1.0 g, $\left.5.38 \mathrm{mmol}\right)$, was dissolved in DCM (20 mL) with catalytic DMF and oxalyl chloride $(577 \mathrm{~mL}, 6.72 \mathrm{mmol})$ was added dropwise at $0{ }^{\circ} \mathrm{C}$ (ice bath). The reaction mixture was stirred at $0{ }^{\circ} \mathrm{C}$ for $45 \mathrm{~min}$ and evaporated under reduced pressure. The residue was dissolved in DCM $(20 \mathrm{~mL})$ with catalytic DMF and DIEA $(2.67 \mathrm{~mL}, 16.14 \mathrm{mmol})$ and Otritylhydroxylamine $(1.259 \mathrm{~g}, 4.573 \mathrm{mmol})$ were added. The reaction mixture was stirred at room temperature for $5 \mathrm{~h}$ and the solvent was removed under reduced pressure. The residue was dissolved in DCM and washed three times with aq $\mathrm{NaHCO}_{3}$ solution (5\%), once with water and the organic layer was dried over $\mathrm{MgSO}_{4}$ and evaporated. The residue was purified by flash chromatography (cyclohexane/ethyl acetate) to give 4-cyclopropylethynyl-N-trityloxy-benzamide (white solid, 46\%). Purity 98\%, ${ }^{1} \mathrm{H}$ NMR 300MHz (DMSO) $\delta$ ppm: $0.72(\mathrm{~m}, 2 \mathrm{H}), 0.88(\mathrm{~m}, 2 \mathrm{H}), 1.53(\mathrm{~m}, 1 \mathrm{H}), 7.34(\mathrm{~m}$, 19H), $10.94(\mathrm{~s}, 1 \mathrm{H}) ; \operatorname{tr}_{\mathrm{LCMS}} 8.31 \mathrm{~min}, \mathrm{MS}[\mathrm{M}+\mathrm{H}]^{+} \mathrm{m} / \mathrm{z} 442, \mathrm{Mp}=155-156{ }^{\circ} \mathrm{C}$. O-Trityle hydroxamate intermediate $(500 \mathrm{mg}, 1.12 \mathrm{mmol})$ was dissolved in TFA 2\%/DCM (20 mL) and triisopropylsilane was added dropwise until the yellow color disappeared. Solvents were removed under reduced pressure 
and the residue was washed with petroleum ether to give compound (19) (93\%). White powder, purity 98\%, ${ }^{1} \mathrm{H}$ NMR 300MHz (DMSO- $\left.d \sigma\right) \delta$ ppm: $0.75(\mathrm{~m}, 2 \mathrm{H}), 0.92(\mathrm{~m}, 2 \mathrm{H}), 1.56(\mathrm{~m}, 1 \mathrm{H}), 7.41(\mathrm{~d}, J=8.5$ $\mathrm{Hz}, 2 \mathrm{H}), 7.69(\mathrm{~d}, J=8.5 \mathrm{~Hz}, 2 \mathrm{H}), 11.24(\mathrm{~s}, 1 \mathrm{H}) ;{ }^{13} \mathrm{C} \mathrm{NMR}(\mathrm{MeOD}) \delta \mathrm{ppm}: 167.5,132.6,132.2,128.9$, $128.1,97.2,75.8,9.1,0.8 ; \operatorname{tr}_{\mathrm{LCMS}} 4.30 \mathrm{~min}, \mathrm{MS}[\mathrm{M}+\mathrm{H}]^{+} \mathrm{m} / \mathrm{z} 200, \mathrm{mp}=171-172{ }^{\circ} \mathrm{C}$.

N-Hydroxy-2-[isobutyl-(4-methoxy-benzenesulfonyl)-amino]-acetamide (20) : To a solution of isopropylamine $(3.5 \mathrm{mmol})$ in DMF $(7 \mathrm{~mL}, 0.5 \mathrm{M})$ was added DIEA $(608 \mu \mathrm{L} ; 3.5 \mathrm{mmol})$ and 4methoxybenzenesulfonylchloride $(3.5 \mathrm{mmol})$ in solution in THF $(7 \mathrm{~mL}, 0.5 \mathrm{M})$. The reaction mixture was stirred at room temperature for $1 \mathrm{~h}$ and the solvents were evaporated under reduced pressure. The residue was dissolved in DCM and washed with $\mathrm{HCl} 1 \mathrm{~N}$ solution and $\mathrm{H}_{2} \mathrm{O}$. The organic layer was dried over $\mathrm{MgSO}_{4}$ and evaporated to give intermediate (20a) (88\%). Purity 95\%, ${ }^{1} \mathrm{H}$ NMR 300MHz $\left(\mathrm{CDCl}_{3}\right) \delta \mathrm{ppm} 0.85(\mathrm{~d} ; J=6.7 \mathrm{~Hz} ; 6 \mathrm{H}) ; 1.65-1.74(\mathrm{~m} ; 1 \mathrm{H}) ; 2.73(\mathrm{t} ; J=6.7 \mathrm{~Hz} ; 2 \mathrm{H}) ; 3.86(\mathrm{~s} ; 3 \mathrm{H}) ;$ 6.94-6.99 (m ; 2H) ; 7.76-7.78 $(\mathrm{m} ; 2 \mathrm{H})$. To a suspension of NaH $(3 \mathrm{mmol})$ in THF $(8 \mathrm{~mL})$ was added (20a) sulfonamide $(3 \mathrm{mmol})$ in THF $(8 \mathrm{~mL})$. The reaction mixture was stirred at room temperature for $30 \mathrm{~min}$ and ethylbromoacetate $(3.3 \mathrm{mmol})$ was added. The reaction mixture was stirred at room temperature overnight and stopped with $\mathrm{H}_{2} \mathrm{O}$. THF was evaporated under reduced pressure and the reaction mixture was extracted with ethyl acetate. The combined organic layers were dried over $\mathrm{MgSO}_{4}$ and evaporated. The residue was purified by TLC (cyclohexane/ethyl acetate 80/20) to give intermediate (20b) (72\%). Purity 98\%, ${ }^{1} \mathrm{H}$ RMN $300 \mathrm{MHz}\left(\mathrm{CDCl}_{3}\right) \delta \mathrm{ppm}: 0.89(\mathrm{~d} ; J=6.7 \mathrm{~Hz} ; 6 \mathrm{H})$; $1.20(\mathrm{t} ; J=7.1 \mathrm{~Hz} ; 2 \mathrm{H}) ; 1.83-1.88(\mathrm{~m} ; 1 \mathrm{H}) ; 3.02(\mathrm{~d} ; J=7.5 \mathrm{~Hz} ; 2 \mathrm{H}) ; 3.86(\mathrm{~s} ; 3 \mathrm{H}) ; 4.01-4.13(\mathrm{~m}$; 4H) ; 6.94-6.99 (m ; 2H) ; 7.75-7.81 (m; 2H). To intermediate (20b) $(3 \mathrm{mmol})$ in $\mathrm{MeOH}(10 \mathrm{~mL})$ was added hydroxylamine hydrochloride $(229 \mathrm{mg} ; 3.3 \mathrm{mmol})$ and sodium methylate $(12.6 \mathrm{~mL} ; 6.3 \mathrm{mmol})$. The reaction mixture was stirred at room temperature overnight and solvents evaporated. $\mathrm{HCl}$ solution $(\mathrm{pH}=3)$ was added and the reaction mixture was extracted with ethyl acetate (5 times). The combined organic layers were dried over $\mathrm{MgSO}_{4}$ and evaporated. The residue was purified by flash chromatography (DCM/MeOH) to give (20) as a solid (53\%) Purity 98\%, NMR ${ }^{1} \mathrm{H} 300 \mathrm{MHz}\left(\mathrm{CDCl}_{3}\right)$ $\delta \mathrm{ppm}: 0.91(\mathrm{~d} ; J=6.7 \mathrm{~Hz} ; 6 \mathrm{H}) ; 1.78-1.84(\mathrm{~m} ; 1 \mathrm{H}) ; 2.94(\mathrm{~d} ; J=7.3 \mathrm{~Hz} ; 2 \mathrm{H}) ; 3.69(\mathrm{~s} ; 2 \mathrm{H}) ; 3.89(\mathrm{~s}$; 
$3 \mathrm{H}) ; 7.01(\mathrm{~d} ; J=8.7 \mathrm{~Hz} ; 2 \mathrm{H}) ; 7.75(\mathrm{~d} ; J=8.8 \mathrm{~Hz} ; 2 \mathrm{H}) ; 9.4(\mathrm{~s} ; 1 \mathrm{H}) ;{ }^{13} \mathrm{C}$ NMR (DMSO- $\left.d 6\right) \delta \mathrm{ppm}:$ $164.9 ; 162.8 ; 131.5 ; 129.9 ; 114.6 ; 56.3 ; 56.1 ; 48.3 ; 26.7 ; 20.5 ; \mathrm{mp}=125-126{ }^{\circ} \mathrm{C}$.

2-(Benzenesulfonyl-isobutyl-amino)-N-hydroxy-acetamide (21): To a solution of isopropylamine $(3.5 \mathrm{mmol})$ in DMF $(7 \mathrm{~mL}, \quad 0.5 \mathrm{M})$ was added DIEA $(608 \mu \mathrm{L} ; 3.5 \mathrm{mmol})$ and benzenesulfonylchloride $(3.5 \mathrm{mmol})$ in solution in THF $(7 \mathrm{~mL}, 0.5 \mathrm{M})$. The reaction mixture was stirred at room temperature for $1 \mathrm{~h}$ and the solvents were evaporated under reduced pressure. The residue was dissolved in DCM and washed with $\mathrm{HCl} 1 \mathrm{~N}$ solution and $\mathrm{H}_{2} \mathrm{O}$. The organic layer was dried over $\mathrm{MgSO}_{4}$ and evaporated to give (21a) (80\%). purity 95\%, ${ }^{1} \mathrm{H} \mathrm{NMR} 300 \mathrm{MHz}\left(\mathrm{CDCl}_{3}\right) \delta \mathrm{ppm}$ $0.85(\mathrm{~d} ; J=6.7 \mathrm{~Hz} ; 6 \mathrm{H}) ; 1.65-1.74(\mathrm{~m} ; 1 \mathrm{H}) ; 2.73(\mathrm{t} ; J=6.7 \mathrm{~Hz} ; 2 \mathrm{H}) ; 3.86(\mathrm{~s} ; 3 \mathrm{H}) ; 6.94-6.99(\mathrm{~m}$; $2 \mathrm{H})$; 7.76-7.78 (m; 2H). To a suspension de $\mathrm{NaH}(3 \mathrm{mmol})$ in THF $(8 \mathrm{~mL})$ was added (21a) sulfonamide $(3 \mathrm{mmol})$ in THF $(8 \mathrm{~mL})$. The reaction mixture was stirred at room temperature for 30min and ethylbromoacetate $(3.3 \mathrm{mmol})$ was added. The reaction mixture was stirred at room temperature overnight and stopped with $\mathrm{H}_{2} \mathrm{O}$. THF was evaporated under reduced pressure and the reaction mixture was extracted with ethyl acetate. The combined organic layers was dried over $\mathrm{MgSO}_{4}$ and evaporated. The residue was purified by TLC (cyclohexane/ethyl acetate 80/20) to give intermediate (21b) (25\%). Purity 95\%, ${ }^{1} \mathrm{H} \mathrm{RMN} 300 \mathrm{MHz}\left(\mathrm{CDCl}_{3}\right) \delta \mathrm{ppm}: 0.90(\mathrm{~d} ; J=6.7 \mathrm{~Hz} ; 6 \mathrm{H})$; $1.16(\mathrm{t} ; J=7.1 \mathrm{~Hz}) ; 1.81-1.86(\mathrm{~m} ; 1 \mathrm{H}) ; 3.06(\mathrm{~d} ; J=6.8 \mathrm{~Hz} ; 2 \mathrm{H}) ; 4.00-4.13(\mathrm{~m} ; 4 \mathrm{H}) ; 7.46-7.60(\mathrm{~m}$; $3 \mathrm{H})$; 7.81-7.85 (m; 2H). To intermediate (21b) (3 mmol) in $\mathrm{MeOH}(10 \mathrm{~mL})$ were added hydroxylamine hydrochloride $(229 \mathrm{mg} ; 3.3 \mathrm{mmol})$ and sodium methylate $(12.6 \mathrm{~mL} ; 6.3 \mathrm{mmol})$. The reaction mixture was stirred at room temperature overnight and solvents evaporated. $\mathrm{HCl}$ solution $(\mathrm{pH}=3)$ was added and the reaction mixture was extracted with ethyl acetate (5 times). The combined organic layers were dried over $\mathrm{MgSO}_{4}$ and evaporated. The residue was purified by TLC (DCM/MeOH 95/5) to give (21) as a solid (29\%) Purity 95\%, NMR ${ }^{1} \mathrm{H} 300 \mathrm{MHz}\left(\mathrm{CDCl}_{3}\right) \delta \mathrm{ppm}: 0.92$ $(\mathrm{d} ; J=6.7 \mathrm{~Hz} ; 6 \mathrm{H}) ; 1.76-1.88(\mathrm{~m} ; 1 \mathrm{H}) ; 2.98(\mathrm{~d} ; J=7.2 \mathrm{~Hz} ; 2 \mathrm{H}) ; 3.72(\mathrm{~s} ; 2 \mathrm{H}) ; 7.54-7.67(\mathrm{~m} ; 3 \mathrm{H})$; $7.81(\mathrm{~d} ; J=8.7 \mathrm{~Hz} ; 2 \mathrm{H}) .{ }^{13} \mathrm{C}$ NMR (DMSO- $\left.d 6\right) \delta \mathrm{ppm}: 164.7 ; 139.7 ; 133.2 ; 129.6 ; 127.7 ; 56.3 ; 48.1$; $26.4 ; 20.3 \mathrm{mp}=122-123^{\circ} \mathrm{C}$ 
((R)-1-Hydroxycarbamoyl-2-phenyl-ethyl)-carbamic acid tert-butyl ester (22): Boc-(D)phenylalanine (500 mg, $1.88 \mathrm{mmol})$ was dissolved in DMF (20 mL). EDCI (433 mg; $2.26 \mathrm{mmol})$; HOBt $(541 \mathrm{mg} ; 2.82 \mathrm{mmol})$ and NMM $(828 \mu \mathrm{L}, 7.5 \mathrm{mmol})$ were added. The mixture was stirred at room temperature for $5 \mathrm{~min}$ and O-Tritylhydroxylamine $(519 \mathrm{mg} ; 1.88 \mathrm{mmol}$ ) was added. The mixture was stirred at room temperature for $72 \mathrm{~h}$. The solvent was evaporated under reduced pressure, the residue was dissolved in DCM and washed three times with aq $\mathrm{NaHCO}_{3}$ solution (5\%), once with water and the organic layer was dried over $\mathrm{MgSO}_{4}$ and evaporated. O-Trityle hydroxamate intermediate was dissolved in TFA 5\%/DCM $(2 \mathrm{~mL})$ and triisopropylsilane $(19 \mu \mathrm{L})$ was added. Solvents were removed under reduced pressure and the residue was washed with diethyl ether/pentane and petroleum ether to give compound (22) (20\%). White powder, purity $98 \%,{ }^{1} \mathrm{H}$ NMR $300 \mathrm{MHz}$ (MeOD) $\delta$ ppm: $1.36(\mathrm{~s}, 9 \mathrm{H}), 2.84(\mathrm{dd}, J=9.0$ and $15.0 \mathrm{~Hz}, 1 \mathrm{H}), 3.04(\mathrm{dd}, J=6.0$ and $12.0 \mathrm{~Hz}, 1 \mathrm{H})$, $4.18(\mathrm{t}, J=6.0 \mathrm{~Hz}, 1 \mathrm{H}), 7.21-7.27(\mathrm{~m}, 5 \mathrm{H}) ;{ }^{13} \mathrm{C}$ NMR (MeOD) $\delta \mathrm{ppm}: 169.5,156.0,136.9,128.9$, 128.0, 126.3, 79.2, 53.8, 38.0, 27.2, $\operatorname{tr}_{\text {LCMS }} 4.36 \mathrm{~min}, \mathrm{MS}[\mathrm{M}-\mathrm{H}]^{-} \mathrm{m} / \mathrm{z} 279$.

\section{Plasma stabilities}

Lithium-heparin plasma from Sprague Dawley rats (mixed gender pool) were from Sera Laboratories International Ltd. Human plasma was a mixed gender pool from donors. PMSF (phenylmethylsulfonyl fluoride) and enalapril maleate were purchased from Sigma-Aldrich.Inc. The experiments were performed in 96-well plates from Matrix Corp. $40 \mu \mathrm{L}$ of a $5 \mathrm{mM}$ solution in DMSO of the sample were added to $1.960 \mathrm{~mL}$ of plasma, previously incubated or not with PMSF at the desired concentration, to obtain a $100 \mu \mathrm{M}$ final solution. The mixture was gently stirred $96 \mathrm{~h}$ at $37^{\circ} \mathrm{C}$. Aliquots of $200 \mu \mathrm{L}$ were taken at various times (from 0 to $96 \mathrm{~h}$ ) and diluted with $200 \mu \mathrm{L}$ of acetonitrile. $10 \mu \mathrm{L}$ of the $2 \mathrm{mM}$ solution in methanol of the internal standard were added. The mixture was centrifugated and supernatant was extracted three times with $2 \mathrm{~mL}$ of AcOEt. The combined organic layers were evaporated and diluted with $200 \mu \mathrm{L}$ of methanol.

For experiments with PMSF, incubations were performed in duplicate in microtiterplates with $80 \mu \mathrm{L}$ of rat plasma (Sprague Dawley pooled mixed gender from Sera Laboratories International Ltd) for 
each time point. Plasma was pre-incubated at $37{ }^{\circ} \mathrm{C} 5 \mathrm{~min}$, then incubated $30 \mathrm{~min}$ with PMSF at a final concentration of $2 \mathrm{mM}$ when needed, before compound addition to a final concentration of $10 \mu \mathrm{M} 1 \%$ DMSO. The reaction was terminated at $0,1,2,4,8,24,48 \mathrm{~h}$ by the addition of acetonitrile containing the internal standard (IS). After centrifugation, supernatant was analyzed.

Analysis and quantification used a LC-MS/MS triple-quadrupole system (Varian 1200ws) under MRM detection using adequate parameters (see Supporting Information for: mode of ionization; declustering potential; collision-activated dissociation and collision energy for each compound). A calibration curve for each compound allowed the linear relationship between concentration and signal intensity (given as peak area ratio analyte/IS). Acquisition and analysis of data were performed with MS Workstation ${ }^{\mathrm{TM}}$ software (version 6.3 .0 or higher). The degradation half-life $\left(\mathrm{t}_{1 / 2}\right)$ values were calculated using the following equation: $t_{1 / 2}=0.693 / \mathrm{k}$ where $\mathrm{k}$ is the first-order degradation rate constant. The degradation rate constant $(\mathrm{k})$ was estimated by one-phase exponential decay non-linear regression analysis of the degradation time course data using $\mathrm{Xlfit}{ }^{\mathrm{TM}}$ software (version 2.1.2 or higher).

\section{Acknowledgements}

We thank Virginie Leroux for technical assistance and Pr. André Tartar for scientific discussion. We are grateful to the institutions that support our laboratory (Inserm, Université Lille Nord de France and Institut Pasteur de Lille) and PRIM: Pôle de Recherche Interdisciplinaire du Médicament. Data management was performed using Pipeline Pilot ${ }^{\mathrm{TM}}$ from Scitegic. We thank also the following institutions or companies: CAMPLP and VARIAN.inc. This project was supported by the Fondation pour la Recherche Medicale; Nord-Pas-de-Calais (RAD07001EEA).

Supporting Information: Mass spectrometry parameters for each compound, exemple of plasma stability curve of $\mathbf{1}$ and enalapril, with or without PMSF, compound $\mathbf{9}$, prodrug $\mathbf{5}$, structures and half-lives of hydroxamates found in the literature (iv or p/o conditions), and 
experimental conditions for compounds 1-3. This material is available free of charge via the internet at http://pubs.acs.org. 


\section{Tables :}

Table 1: Reaction conditions for the coupling of N-methyl hydroxylamine with $\mathbf{4 b}$.

\begin{tabular}{cccccc}
\hline Reagent & Solvent & $\begin{array}{c}\text { Temp. } \\
\left({ }^{\circ} \mathrm{C}\right)\end{array}$ & $\begin{array}{c}\text { Time } \\
(\mathrm{h})\end{array}$ & $\begin{array}{c}\text { Conversion } \\
(\%)\end{array}$ & Comments \\
\hline Oxalyl chloride ${ }^{44}$ & $\mathrm{DCM}$ & 0 then $\mathrm{rt}$ & 4 & 27 & Complex mixture \\
Ethyl chloroformate & $\mathrm{DCM}$ & 0 then $\mathrm{rt}$ & 1.5 & - & Obtention of diethyl ester \\
TBTU / HOBt & $\mathrm{DMF}$ & $\mathrm{rt}$ & overnight & 60 & Complex mixture \\
EDCI / HOBt & $\mathrm{DMF}$ & $\mathrm{rt}$ & overnight & 25 & Complex mixture \\
PyBrop & DMF/DCM & $\mathrm{rt}$ & overnight & 70 & \\
\hline
\end{tabular}

a. $\quad$ 4b conversion to final product determined by HPLC $(215 \mathrm{~nm})$ 
Table 2: Influence of PMSF on plasma stability of 1 and enalapril ( $t_{1 / 2}$ in $\left.h\right)$.

\begin{tabular}{rcc}
\hline \multicolumn{1}{c}{ Cpd } & w/o PMSF & 2mM PMSF \\
\hline $\mathbf{1}$ & 0.8 & 15 \\
\hline enalapril & 0.05 & $>24$ \\
\hline
\end{tabular}


Table 3: Rat plasma stabilities of analogues of malonyl hydroxamic acid 1.

(E)-2


Table 4: Rat plasma stabilities of hydroxamic acids 11-22.

\begin{tabular}{|c|c|c|}
\hline & $11-23$ & \\
\hline Cpd & $-\mathbf{R}$ & $t_{1 / 2}(h)$ \\
\hline 11 & & 1.3 \\
\hline 12 & $\mathrm{Ph}-$ & $>24.0$ \\
\hline 13 & $\mathrm{Ph}-\mathrm{CH}_{2}-$ & $>24.0$ \\
\hline 14 & $\mathrm{Ph}-\left(\mathrm{CH}_{2}\right)_{2-}$ & 1.5 \\
\hline 15 & $\mathrm{Ph}-\left(\mathrm{CH}_{2}\right)_{3^{-}}$ & 2.0 \\
\hline 16 & $\mathrm{Ph}-\mathrm{CH}=\mathrm{CH}-$ & 6.2 \\
\hline 17 & $\mathrm{Ph}-\mathrm{O}-\mathrm{CH}_{2}-$ & 3.0 \\
\hline 18 & $\mathrm{Ph}-\mathrm{O}-\left(\mathrm{CH}_{2}\right)_{2-}$ & 1.4 \\
\hline 19 & & 4.0 \\
\hline 20 & & 10.5 \\
\hline 21 & & 9.6 \\
\hline 22 & & $<1$ \\
\hline SAHA & & 9.7 \\
\hline
\end{tabular}


Table 5 : Comparing stabilities of analogues of 14.

\begin{tabular}{|c|c|c|}
\hline 1,11 & (E)-2,16 & (Z)-2 \\
\hline Cpd & R- & $\mathbf{t}_{1 / 2}(\mathbf{h})$ \\
\hline 14 & H- & 1.5 \\
\hline $22^{\mathrm{a}}$ & Boc-NH- & $<1$ \\
\hline 1 & $\mathrm{~F}-\mathrm{C}_{6} \mathrm{H}_{4}-\mathrm{CH}_{2}-\mathrm{NHCO}-$ & 0.8 \\
\hline 11 & $\mathrm{~F}-\mathrm{C}_{6} \mathrm{H}_{4}-\mathrm{CH}_{2}-\mathrm{CONH}-$ & 1.0 \\
\hline 16 & H- & 6.2 \\
\hline (E)-2 & $\mathrm{F}-\mathrm{C}_{6} \mathrm{H}_{4}-\mathrm{CH}_{2}-\mathrm{NHCO}-$ & 4.1 \\
\hline (Z)-2 & $\mathrm{F}-\mathrm{C}_{6} \mathrm{H}_{4}-\mathrm{CH}_{2}-\mathrm{NHCO}-$ & 22.0 \\
\hline
\end{tabular}

${ }^{\mathrm{a}}$ :derived from D-Phe. 
Table 6: Enhancement of apparent half-life of 1 using prodrug 5.

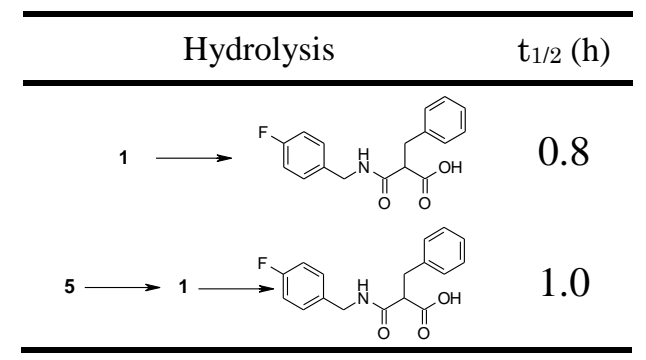


Table 7: Comparison of Stability $\left(t_{1 / 2}\right.$ in $\left.h\right)$ in various media.

\begin{tabular}{rccc}
\hline \multicolumn{1}{c}{ Cpd } & $\begin{array}{c}\text { Rat } \\
\text { plasma }\end{array}$ & $\begin{array}{c}\text { Human } \\
\text { plasma }\end{array}$ & $\begin{array}{c}\text { Buffer } \\
(\text { PBS , pH=7.4) }\end{array}$ \\
\hline $\mathbf{1}$ & 0.8 & $>24$ & $>24$ \\
\hline $\mathbf{E})-\mathbf{2}$ & 4.1 & $>24$ & $>24$ \\
\hline $\mathbf{Z})-\mathbf{2}$ & 22 & $>24$ & $>24$ \\
\hline $\mathbf{1 4}$ & 1.7 & $>24$ & $>24$ \\
\hline $\mathbf{1 5}$ & 1.3 & $>24$ & $>24$ \\
\hline
\end{tabular}




\section{Schemes}

$R-\overbrace{\mathrm{O}}^{\mathrm{N}-\mathrm{OH}} \longrightarrow \mathrm{R}-\overbrace{\mathrm{O}}^{\mathrm{OH}}$

Scheme 1: Metabolic hydrolysis of hydroxamic acids in plasma. 


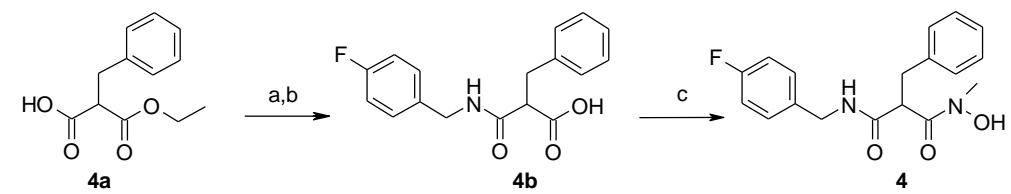

Scheme 2: Synthesis of compound 4.

Reagents and conditions: a.1) CDI, THF, DIEA, DMF, $1.5 \mathrm{~h}$, room temp. 2) p-F- $\mathrm{C}_{6} \mathrm{H}_{4}-\mathrm{CH}_{2}-\mathrm{NH}_{2}$, room temp., 3 h, $81 \%$, a) KOH, abs. EtOH, 12 h, room temp., 80\% c) PyBrop, $\mathrm{CH}_{3}-\mathrm{NH}-\mathrm{OH}, \mathrm{CH}_{2} \mathrm{Cl}_{2}$, DIEA/DMF, 12 h, room temp., $40 \%$. 


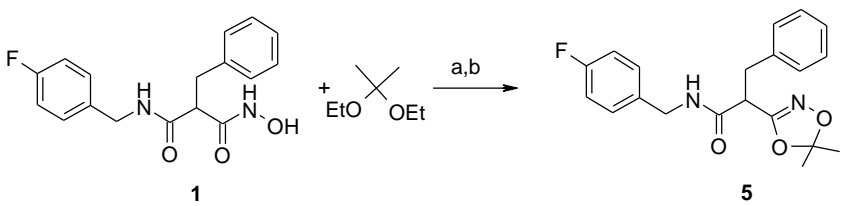

Scheme 3: Synthesis of prodrug 5.

Reagents and conditions: a. camphor sulfonic acid, $\mathrm{CH}_{2} \mathrm{Cl}_{2}, 2$ h, room temp., $80 \%$ b. NaOH $0.1 \mathrm{M}$, dioxane, 3.5 h, room temp., $50 \%$. 


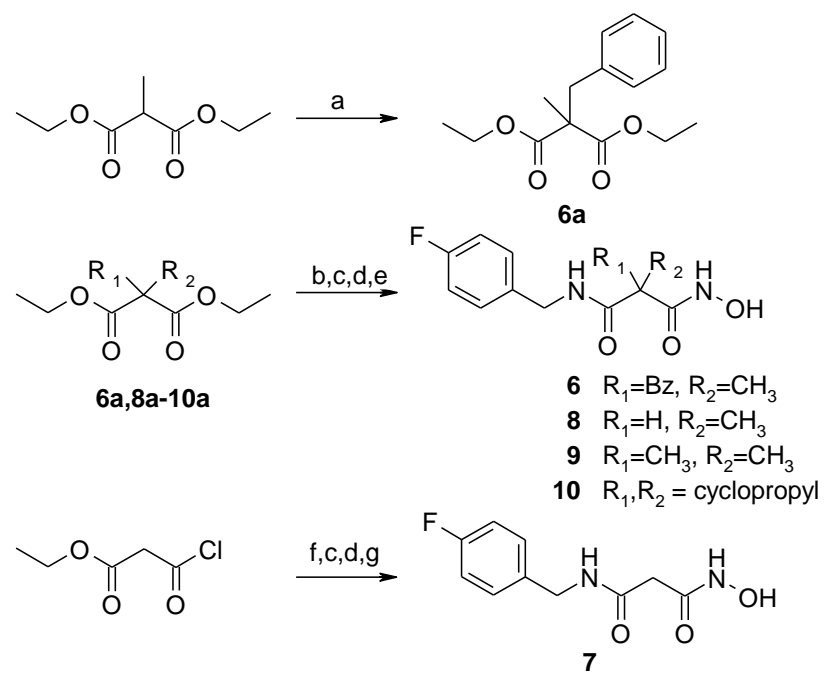

\section{Scheme 4: Synthesis of compounds 6-10.}

Reagents and conditions: a. 1) EtONa/EtOH, 1 h, $\left.50{ }^{\circ} \mathrm{C}, 2\right) \mathrm{C}_{6} \mathrm{H}_{5} \mathrm{CH}_{2} \mathrm{Br}, 2 \mathrm{~h}, 50{ }^{\circ} \mathrm{C}, 83 \%$. b. KOH, abs. EtOH, 4 h, room temp., $80 \%$ c. $p$-fluoro-benzylamine, EDCI/HOBt, DMF, DIEA, room temp., 12 h. d. KOH, abs. EtOH, $12 \mathrm{~h}$, room temp. e. 1) ethyl chloroformate, TEA, $\mathrm{CH}_{2} \mathrm{Cl}_{2}, 40$ min., $0{ }^{\circ} \mathrm{C}$. 2) $\mathrm{H}_{2} \mathrm{NO}-\mathrm{Trt}, 1 \mathrm{~h}$, room temp. 3) TFA $2 \% / \mathrm{CH}_{2} \mathrm{Cl}_{2}$, triisopropylsilane, 5 min. room temp. f. $\mathrm{H}_{2} \mathrm{NOTrt}$, DIEA, $\mathrm{CH}_{2} \mathrm{Cl}_{2}, 3$ h, room temp., $79 \%$. g. TFA $2 \% / \mathrm{CH}_{2} \mathrm{Cl}_{2}$, triisopropylsilane, 5 min. room temp. 


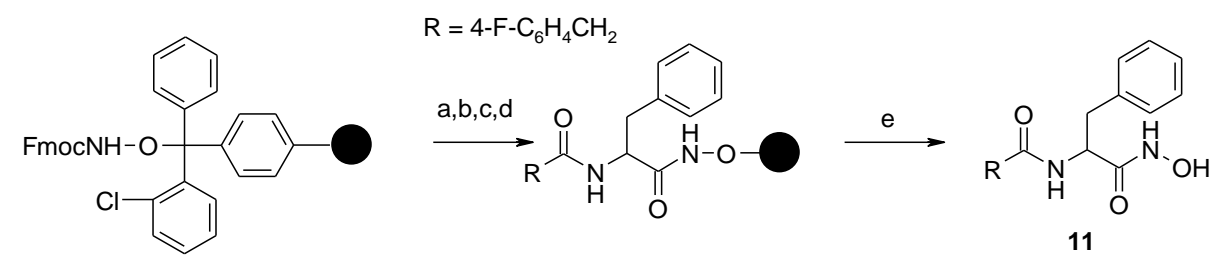

Scheme 5: Solid-phase synthesis of 11.

Reagents and conditions: a. piperidine 20\%/DMF 80\%, 45 min (twice). b. D,L Fmoc-Phe-OH, HATU, DIEA, DMF, 12 h (twice) c. piperidine 20\%/DMF 80\%, 45 min (twice) d. RCOOH, HOBt, TBTU, DIEA, DMF (twice) e. TFA $2 \% / \mathrm{CH}_{2} \mathrm{Cl}_{2}$, triisopropylsilane, 5 min. (twice). 

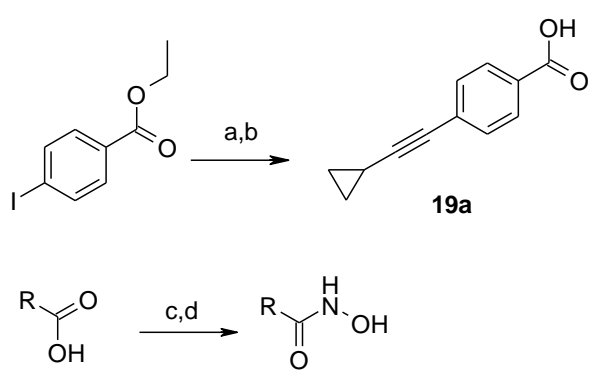

12a-22a $\quad 12-22$

Scheme 6: Synthesis of compounds 19a, 12-22.

Reagents and conditions: a. cyclopropylacetylene, $\mathrm{PdCl}_{2}\left(\mathrm{PPh}_{3}\right)_{2}, \mathrm{CuI}, \mathrm{NEt} 3, \mathrm{DMF}, 70{ }^{\circ} \mathrm{C}, 90 \%$ b. $\mathrm{NaOH}, \mathrm{EtOH}$, $\mathrm{H}_{2} \mathrm{O}$, room temp. $98 \%$ c. oxalylchloride (1.2 eq), DCM, cat. DMF, 45 min., $0{ }^{\circ} \mathrm{C}$; (ii) DIEA (3 eq), Otritylhydroxylamine (0.85 eq), DCM, $0{ }^{\circ} \mathrm{C}$ then room temp., $3 \mathrm{~h}$; or carboxylic acid $0.1 \mathrm{M} / \mathrm{DMF}(1 \mathrm{eq})$, DIEA (2.4 eq), EDCI (1.1 eq), HOBt (1.1 eq), room temp. 5 min. then O-tritylhydroxylamine ( 0.85 eq) $0.1 \mathrm{M} / \mathrm{DMF}$, DIEA (2 eq), room temp., $5 \mathrm{~h}$ d. TFA 2\% / DCM, triisopropylsilane, 5 min., room temp. 


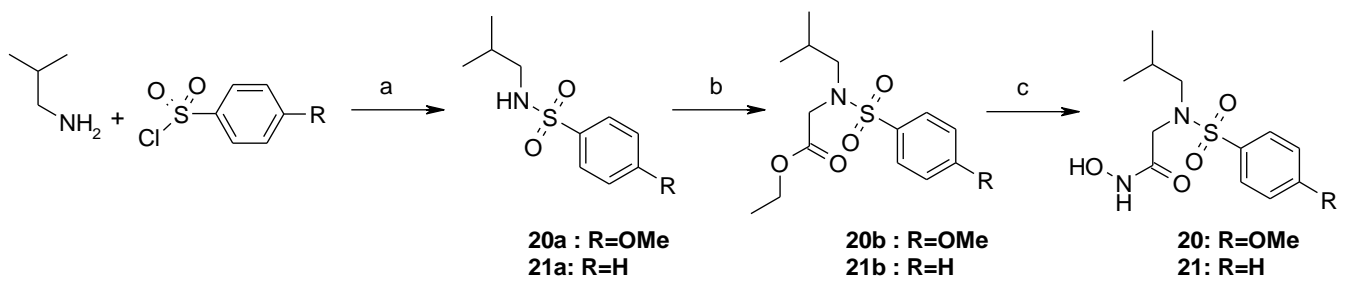

Scheme 7: Synthesis of derivatives 20-21.

Reagents and conditions : a. DIEA, DMF, THF, room temp., 1 h. b. NaH, Ethylbromoacetate, THF, room temp., 12 h. c. $\mathrm{NH}_{2} \mathrm{OH} . \mathrm{HCl}, \mathrm{NaOMe}, \mathrm{MeOH}$, room temp., 12 h. 
Figures
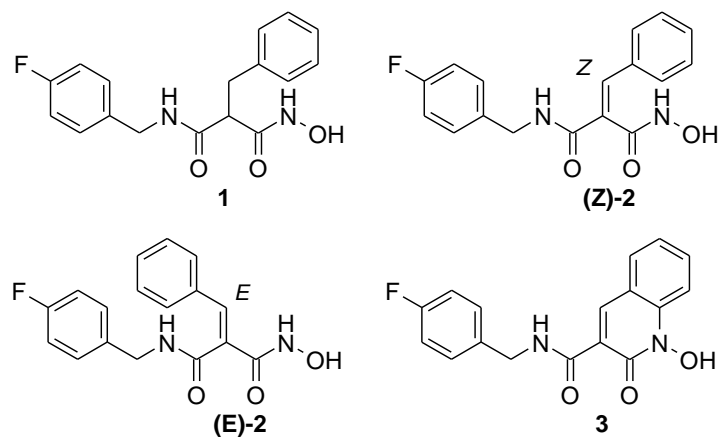

Figure 1: Structures of compounds 1-3.
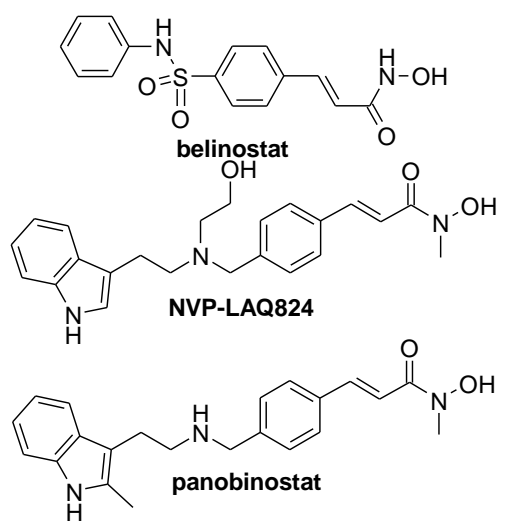

Figure 2: Structures of NVP-LAQ824, panobinostat (NVP- LBH589) and belinostat (PXD101).

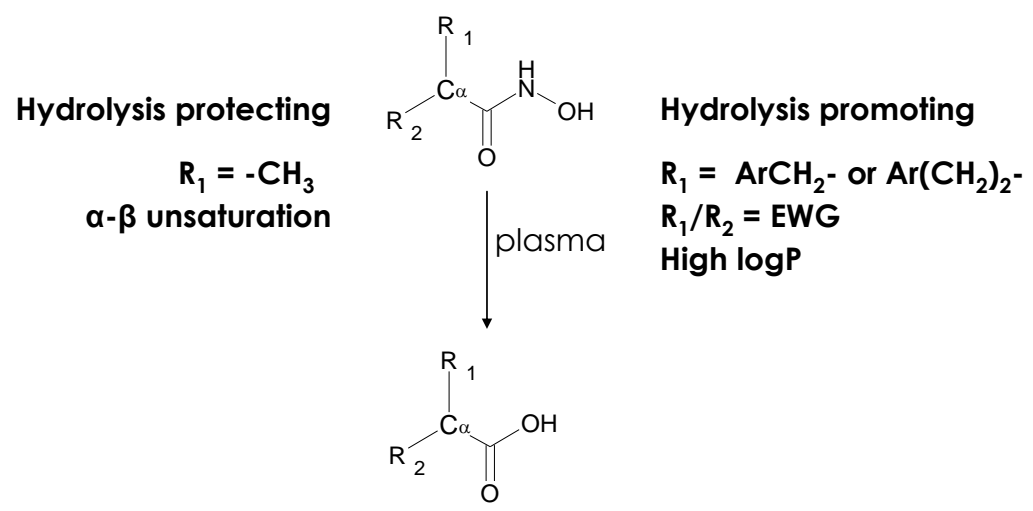

Figure 3 : Hydrolysis promoting or protecting factors. ${ }^{a}$

${ }^{a}$ EWG: Electron-Withdrawing Group 


\section{References and notes}

${ }^{1}$ A search within MDL Drug Data Report from Prous Science Publisher, retrieves 1938 bioactive hydroxamates (June 2008).

${ }^{2}$ Lou, B.; Yang, K., Molecular diversity of hydroxamic acids: part II. Potential therapeutic applications. Mini Rev. Med. Chem. 2003, 3, (6), 609-20.

${ }^{3}$ Sieber, S. A.; Niessen, S.; Hoover, H. S.; Cravatt, B. F., Proteomic profiling of metalloprotease activities with cocktails of active-site probes. Nat Chem Biol 2006, 2, (5), 274-281.

${ }^{4}$ Marmion, C. J.; Griffith, D.; Nolan, K. B., Hydroxamic Acids - An Intriguing Family of Enzyme Inhibitors and Biomedical Ligands. European Journal of Inorganic Chemistry 2004, 2004, (15), 3003-3016.

${ }^{5}$ Boularot, A.; Giglione, C.; Petit, S.; Duroc, Y.; Alves de Sousa, R.; Larue, V.; Cresteil, T.; Dardel, F.; Artaud, I.; Meinnel, T., Discovery and refinement of a new structural class of potent peptide deformylase inhibitors. $J$ Med Chem 2007, 50, (1), 10-20.

${ }^{6}$ Capkova, K.; Yoneda, Y.; Dickerson, T. J.; Janda, K. D., Synthesis and structure-activity relationships of second-generation hydroxamate botulinum neurotoxin A protease inhibitors. Bioorg. Med. Chem. Lett. 2007, 17, (23), 6463.

${ }^{7}$ Yao, W.; Zhuo, J.; Burns, D. M.; Xu, M.; Zhang, C.; Li, Y. L.; Qian, D. Q.; He, C.; Weng, L.; Shi, E.; Lin, Q.; Agrios, C.; Burn, T. C.; Caulder, E.; Covington, M. B.; Fridman, J. S.; Friedman, S.; Katiyar, K.; Hollis, G.; Li, Y.; Liu, C.; Liu, X.; Marando, C. A.; Newton, R.; Pan, M.; Scherle, P.; Taylor, N.; Vaddi, K.; Wasserman, Z. R.; Wynn, R.; Yeleswaram, S.; Jalluri, R.; Bower, M.; Zhou, B. B.; Metcalf, B., Discovery of a Potent, Selective, and Orally Active Human Epidermal Growth Factor Receptor-2 Sheddase Inhibitor for the Treatment of Cancer. J. Med. Chem. 2007, 50, (4), 603-606.

${ }^{8}$ Noe, M. C.; Natarajan, V.; Snow, S. L.; Mitchell, P. G.; Lopresti-Morrow, L.; Reeves, L. M.; Yocum, S. A.; Carty, T. J.; Barberia, J. A.; Sweeney, F. J.; Liras, J. L.; Vaughn, M.; Hardink, J. R.; Hawkins, J. M.; Tokar, C., Discovery of 3,3-dimethyl-5-hydroxypipecolic hydroxamate-based inhibitors of aggrecanase and MMP-13. Bioorg. Med. Chem. Lett. 2005, 15, (11), 2808.

${ }^{9}$ Zhu, Z.; Mazzola, R.; Sinning, L.; McKittrick, B.; Niu, X.; Lundell, D.; Sun, J.; Orth, P.; Guo, Z.; Madison, V.; Ingram, R.; Beyer, B. M., Discovery of Novel Hydroxamates as Highly Potent Tumor Necrosis FactorConverting Enzyme Inhibitors: Part I:Discovery of Two Binding Modes. J. Med. Chem. 2008, 51, (4), 725-736. 
${ }^{10}$ Flipo, M.; Beghyn, T.; Leroux, V.; Florent, I.; Deprez, B. P.; Deprez-Poulain, R. F., Novel Selective Inhibitors of the Zinc Plasmodial Aminopeptidase PfA-M1 as Potential Antimalarial Agents. J. Med. Chem. 2007, 50, (6), $1322-1334$.

${ }^{11}$ Chen, Y. F.; Lopex-Sanchez, M.; Savoy, D. N.; Billadieu, D. D.; Dow, G. S.; Kozikowski, A. P., A series of potent and selective, triazolylphenyl-based histone deacetylase inhibitors [HDACIs] with activity against pancreatic cancer cells and plasmodium falciparum. J. Med. Chem. 2008, 51, (12), 3437-3448.

12 (a) Charrier, C.; Clarhaut, J.; Gesson, J.-P.; Estiu, G.; Wiest, O.; Roche, J.; Bertrand, P., Synthesis and Modeling of New Benzofuranone Histone Deacetylase Inhibitors that Stimulate Tumor Suppressor Gene Expression. J. Med. Chem. 2009, 52, (9), 3112-3115. (b) Smil, D. V.; Manku, S.; Chantigny, Y. A.; Leit, S.; Wahhab, A.; Yan, T. P.; Fournel, M.; Maroun, C.; Li, Z.; Lemieux, A.-M.; Nicolescu, A.; Rahil, J.; Lefebvre, S.; Panetta, A.; Besterman, J. M.; Déziel, R., Novel HDAC6 isoform selective chiral small molecule histone deacetylase inhibitors. Bioorg. Med. Chem. Lett. 2009, 19, (3), 688-692.

${ }^{13}$ Becker, D. P.; Villamil, C. I.; Barta, T. E.; Bedell, L. J.; Boehm, T. L.; DeCrescenzo, G. A.; Freskos, J. N.; Getman, D. P.; Hockerman, S.; Heintz, R.; Howard, S. C.; Li, M. H.; McDonald, J. J.; Carron, C. P.; FunckesShippy, C. L.; Mehta, P. P.; Munie, G. E.; Swearingen, C. A., Synthesis and Structure-Activity Relationships of beta- and alpha-Piperidine Sulfone Hydroxamic Acid Matrix Metalloproteinase Inhibitors with Oral Antitumor Efficacy. J. Med. Chem. 2005, 48, (21), 6713-6730.

${ }^{14}$ Lombart, H. G.; Feyfant, E.; Joseph-McCarthy, D.; Huang, A.; Lovering, F.; Sun, L.; Zhu, Y.; Zeng, C.; Zhang, Y.; Levin, J., Design and synthesis of 3,3-piperidine hydroxamate analogs as selective TACE inhibitors. Bioorg. Med. Chem. Lett. 2007, 17, (15), 4333-7.

15 Puerta, D. T.; Lewis, J. A.; Cohen, S. M., New beginnings for matrix metalloproteinase inhibitors: identification of high-affinity zinc-binding groups. J. Am. Chem. Soc. 2004, 126, (27), 8388-9.

${ }^{16}$ Pikul, S.; Ohler, N. E.; Ciszewski, G.; Laufersweiler, M. C.; Almstead, N. G.; De, B.; Natchus, M. G.; Hsieh, L. C.; Janusz, M. J.; Peng, S. X.; Branch, T. M.; King, S. L.; Taiwo, Y. O.; Mieling, G. E., Potent and selective carboxylic acid-based inhibitors of matrix metalloproteinases. J Med Chem 2001, 44, (16), 2499-502.

${ }^{17}$ Suzuki, T.; Matsuura, A.; Kouketsu, A.; Hisakawa, S.; Nakagawa, H.; Miyata, N., Design and synthesis of non-hydroxamate histone deacetylase inhibitors: identification of a selective histone acetylating agent. Bioorg. Med. Chem. 2005, 13, (13), 4332. 
${ }^{18}$ Nagaoka, Y.; Maeda, T.; Kawai, Y.; Nakashima, D.; Oikawa, T.; Shimoke, K.; Ikeuchi, T.; Kuwajima, H.; Uesato, S., Synthesis and cancer antiproliferative activity of new histone deacetylase inhibitors: hydrophilic hydroxamates and 2-aminobenzamide-containing derivatives. Eur. J. Med. Chem. 2006, 41, (6), 697.

${ }^{19}$ Michaelides, M. R.; Dellaria, J. F.; Gong, J.; Holms, J. H.; Bouska, J. J.; Stacey, J.; Wada, C. K.; Heyman, H. R.; Curtin, M. L.; Guo, Y.; Goodfellow, C. L.; Elmore, I. B.; Albert, D. H.; Magoc, T. J.; Marcotte, P. A.; Morgan, D. W.; Davidsen, S. K., Biaryl ether retrohydroxamates as potent, long-lived, orally bioavailable MMP inhibitors. Bioorg. Med. Chem. Lett. 2001, 11, (12), 1553-6.

${ }^{20}$ Grant, S.; Easley, C.; Kirkpatrick, P., Vorinostat. Nat. Rev. Drug Discov. 2007, 6, (1), 21.

${ }^{21}$ Sanderson, L.; Taylor, G. W.; Aboagye, E. O.; Alao, J. P.; Latigo, J. R.; Coombes, R. C.; Vigushin, D. M., Plasma pharmacokinetics and metabolism of the histone deacetylase inhibitor trichostatin a after intraperitoneal administration to mice. Drug Metab. Dispos. 2004, 32, (10), 1132-8.

${ }^{22}$ Obach, R. S., Potent inhibition of human liver aldehyde oxidase by raloxifene. Drug Metab. Dispos. 2004, 32, (1), 89-97.

${ }^{23}$ Honohan, T.; Fitzpatrick, F. A.; Booth, D. G.; McGrath, J. P.; Morton, D. R.; Nishizawa, E., Hydrolysis of an orally active platelet inhibitory prostanoid amide in the plasma of several species. Prostaglandins 1980, 19, (1), $123-36$.

24 Li, B.; Sedlacek, M.; Manoharan, I.; Boopathy, R.; Duysen, E. G.; Masson, P.; Lockridge, O., Butyrylcholinesterase, paraoxonase, and albumin esterase, but not carboxylesterase, are present in human plasma. Biochem. Pharmacol. 2005, 70, (11), 1673.

${ }^{25}$ Weisburger, J. H.; Weisburger, E. K., Biochemical Formation and Pharmacological, Toxicological, and Pathological Properties of Hydroxylamines and Hydroxamic Acids. Pharmacol. Rev. 1973, 25, (1), 1-66.

${ }^{26}$ Du, L.; Musson, D. G.; Wang, A. Q., Stability studies of vorinostat and its two metabolites in human plasma, serum and urine. J. Pharm. Biomed. Anal. 2006, 42, (5), 556.

${ }^{27}$ Mulder, G. J.; Meerman, J. H., Sulfation and glucuronidation as competing pathways in the metabolism of hydroxamic acids: the role of N,O-sulfonation in chemical carcinogenesis of aromatic amines. Environ. Health Perspect. 1983, 49, 27-32.

${ }^{28}$ Thomas, M.; Rivault, F.; Tranoy-Opalinski, I.; Roche, J.; Gesson, J.-P.; Papot, S., Synthesis and biological evaluation of the suberoylanilide hydroxamic acid (SAHA) [beta]-glucuronide and [beta]-galactoside for application in selective prodrug chemotherapy. Bioorg. Med. Chem. Lett. 2007, 17, (4), 983. 
${ }^{29}$ Hajduk, P. J.; Shuker, S. B.; Nettesheim, D. G.; Craig, R.; Augeri, D. J.; Betebenner, D.; Albert, D. H.; Guo, Y.; Meadows, R. P.; Xu, L.; Michaelides, M.; Davidsen, S. K.; Fesik, S. W., NMR-based modification of matrix metalloproteinase inhibitors with improved bioavailability. J. Med. Chem. 2002, 45, (26), 5628-39.

${ }^{30}$ US Patent 6,770,644 B1, Aug. 3, 2004, from Ono Pharmaceuticals.

${ }^{31}$ Couturier, M.; Tucker, J. L.; Proulx, C.; Boucher, G.; Dube, P.; Andresen, B. M.; Ghosh, A., 5,5-Dimethyl1,4,2-dioxazoles as Versatile Aprotic Hydroxamic Acid Protecting Groups. J. Org. Chem. 2002, 67, (14), 48334838.

${ }^{32}$ MacPherson, L. J.; Bayburt, E. K.; Capparelli, M. P.; Carroll, B. J.; Goldstein, R.; Justice, M. R.; Zhu, L.; Hu, S.; Melton, R. A.; Fryer, L.; Goldberg, R. L.; Doughty, J. R.; Spirito, S.; Blancuzzi, V.; Wilson, D.; O'Byrne, E. M.; Ganu, V.; Parker, D. T., Discovery of CGS 27023A, a Non-Peptidic, Potent, and Orally Active Stromelysin Inhibitor That Blocks Cartilage Degradation in Rabbits. J. Med. Chem. 1997, 40, (16), 2525-2532.

${ }^{33}$ Gediya, L. K.; Chopra, P.; Purushottamachar, P.; Maheshwari, N.; Njar, V. C. O., A New Simple and HighYield Synthesis of Suberoylanilide Hydroxamic Acid and Its Inhibitory Effect Alone or in Combination with Retinoids on Proliferation of Human Prostate Cancer Cells. J. Med. Chem. 2005, 48, (15), 5047-5051.

${ }^{34}$ Half-lives longer than $24 \mathrm{~h}$, data not shown.

${ }^{35}$ Summers, J. B.; Gunn, B. P.; Mazdiyasni, H.; Goetze, A. M.; Young, P. R.; Bouska, J. B.; Dyer, R. D.; Brooks, D. W.; Carter, G. W., In vivo characterization of hydroxamic acid inhibitors of 5-lipoxygenase. J. Med. Chem. 1987, 30, (11), 2121-2126.

${ }^{36}$ AlogP were calculated using PipelinePilot from Accelrys ${ }^{\mathrm{TM}}$.

${ }^{37}$ Beneficial or deleterious influence of lipophilicity on hydrolytic reactivity for some esters has been studied in Redden, P. R.; Melanson, R. L.; Douglas, J.-A. E.; Dick, A. J., Acyloxymethyl acidic drug derivatives: in vitro hydrolytic reactivity. Int. J. Pharm. 1999, 180, (2), 151.

${ }^{38}$ Gilmore, J. L.; King, B. W.; Harris, C.; Maduskuie, T.; Mercer, S. E.; Liu, R.-Q.; Covington, M. B.; Qian, M.; Ribadeneria, M. D.; Vaddi, K., Synthesis and structure-activity relationship of a novel, achiral series of TNF[alpha] converting enzyme inhibitors. Bioorg. Med. Chem. Lett. 2006, 16, (10), 2699-2704.

${ }^{39}$ See stability curves supporting information.

${ }^{40}$ a. Drummond, D. C.; Marx, C.; Guo, Z.; Scott, G.; Noble, C.; Wang, D.; Pallavicini, M.; Kirpotin, D. B.; Benz, C. C., Enhanced Pharmacodynamic and Antitumor Properties of a Histone Deacetylase Inhibitor Encapsulated in Liposomes or ErbB2-Targeted Immunoliposomes. Clin. Cancer Res. 2005, 11, (9), 3392-3401. b. Mahboobi, S.; Sellmer, A.; Hocher, H.; Garhammer, C.; Pongratz, H.; Maier, T.; Ciossek, T.; Beckers, T., 2- 
Aroylindoles and 2-Aroylbenzofurans with N-Hydroxyacrylamide Substructures as a Novel Series of Rationally Designed Histone Deacetylase Inhibitors. J. Med. Chem. 2007, 50, (18), 4405-4418.

${ }^{41}$ Capková, K.; Yoneda, Y.; Dickerson, T. J.; Janda, K. D., Synthesis and structure-activity relationships of second-generation hydroxamate botulinum neurotoxin A protease inhibitors. Bioorg. Med. Chem. Lett. 2007, 17, (23), 6463 .

${ }^{42}$ Search in clinicaltrials.org, March 2009.

${ }^{43}$ Kim, H. M.; Oh, S. J.; Park, S. K.; Han, G.; Kim, K.; Lee, K. S.; Kang, J. S.; Nam, M.; Lee, K., In vitro metabolism of KBH-A40, a novel $\delta$-lactam-based histone deacetylase (HDAC) inhibitor, in human liver microsomes and serum. Xenobiotica 2008, 38, (3), 281 - 293.

${ }^{44}$ Summers, J. B.; Gunn, B. P.; Mazdiyasni, H.; Goetze, A. M.; Young, P. R.; Bouska, J. B.; Dyer, R. D.; Brooks, D. W.; Carter, G. W., In vivo characterization of hydroxamic acid inhibitors of 5-lipoxygenase. J. Med. Chem. 1987, 30, (11), 2121-2126.

${ }^{45}$ Huang, F. C.; Shoupe, T. S.; Lin, C. J.; Lee, T. D. Y.; Chan, W. K.; Tan, J.; Schnapper, M.; Suh, J. T.; Gordon, R. J.; et al., Differential effects of a series of hydroxamic acid derivatives on 5-lipoxygenase and cyclooxygenase from neutrophils and 12-lipoxygenase from platelets and their in vivo effects on inflammation and anaphylaxis. J. Med. Chem. 1989, 32, (8), 1836-1842. 


\section{TOC Graphic}

Hydroxamates : Relationships between structure and plasma-stability.

Marion Flipo ; Julie Charton; Akila Hocine ; Sandrine Dassonneville ; Benoit Deprez ;

Rebecca Deprez-Poulain.

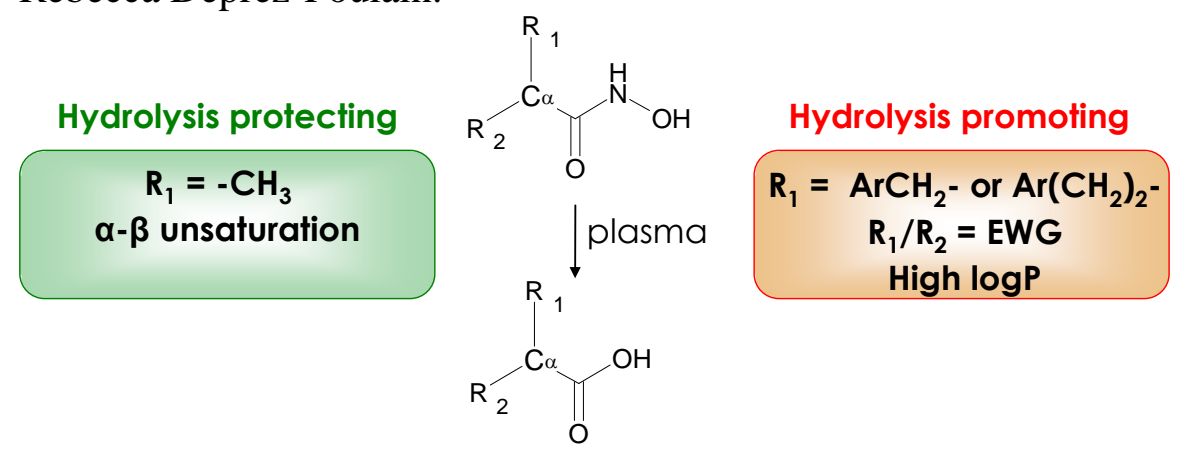

